\title{
Modeling the Adequacy of Dietary Fiber in Dairy Cows Based on the Responses of Ruminal pH and Milk Fat Production to Composition of the Diet
}

\author{
Q. Zebeli, ${ }^{\star 1}$ J. Dijkstra, $†$ M. Tafaj, ${ }^{*}$ H. Steingass, ${ }^{*}$ B. N. Ametaj, $\ddagger$ and W. Drochner* \\ *Institute of Animal Nutrition (450), University of Hohenheim, Emil-Wolff-Str. 10, D-70599 Stuttgart, Germany \\ †Animal Nutrition Group, Wageningen University, Marijkeweg 40, 6709 PG Wageningen, the Netherlands \\ łDepartment of Agricultural, Food and Nutritional Science, University of Alberta, Edmonton, Alberta T6G 2P5 Canada
}

\begin{abstract}
The main objective of this study was to develop practical models to assess and predict the adequacy of dietary fiber in high-yielding dairy cows. We used quantitative methods to analyze relevant research data and critically evaluate and determine the responses of ruminal $\mathrm{pH}$ and production performance to different variables including physical, chemical, and starch-degrading characteristics of the diet. Further, extensive data were used to model the magnitude of ruminal $\mathrm{pH}$ fluctuations and determine the threshold for the development of subacute ruminal acidosis (SARA). Results of this study showed that to minimize the risk of SARA, the following events should be avoided: 1) a daily mean ruminal $\mathrm{pH}$ lower than 6.16, and 2) a time period in which ruminal $\mathrm{pH}$ is $<5.8$ for more than $5.24 \mathrm{~h} / \mathrm{d}$. As the content of physically effective neutral detergent fiber (peNDF) or the ratio between peNDF and rumen-degradable starch from grains in the diet increased up to $31.2 \pm 1.6 \%$ [dry matter (DM) basis] or $1.45 \pm 0.22$, respectively, so did the daily mean ruminal $\mathrm{pH}$, for which a asymptotic plateau was reached at a $\mathrm{pH}$ of 6.20 to 6.27. This study also showed that digestibility of fiber in the total tract depends on ruminal $\mathrm{pH}$ and outflow rate of digesta from reticulorumen; thereby both variables explained $62 \%$ of the variation of fiber digestibility. Feeding diets with peNDF content up to $31.9 \pm 1.97 \%$ (DM basis) slightly decreased DM intake and actual milk yield; however, $3.5 \%$ fat-corrected milk and milk fat yield were increased, resulting in greater milk energy efficiency. In conclusion, a level of about 30 to $33 \%$ peNDF in the diet may be considered generally optimal for minimizing the risk of SARA without impairing important production responses in high-yielding dairy cows. In terms of improvement of the accuracy to assessing dietary fiber
\end{abstract}

Received August 3, 2007.

Accepted January 8, 2008

${ }^{1}$ Corresponding author: zebeli@uni-hohenheim.de adequacy, it is suggested that the content of peNDF required to stabilize ruminal $\mathrm{pH}$ and maintain milk fat content without compromising milk energy efficiency can be arranged based on grain or starch sources included in the diet, on feed intake level, and on days in milk of the cows.

Key words: physically effective fiber, dairy cow, ruminal $\mathrm{pH}$, rumen-degradable starch

\section{INTRODUCTION}

The challenge primarily met in dairy cow feeding is to provide an energetically high-density ration without compromising ruminal ecosystem, animal welfare, and production performances. Providing high-yielding dairy cows adequate levels of dietary fiber is critical to prevent subacute ruminal acidosis (SARA) and the resulting depressions in fiber digestion, DMI, and milk production as well as alterations in milk composition (NRC, 2001). In contrast, offering diets in excess of fiber may decrease feed intake and lower the efficiency of feed use (Yang and Beauchemin, 2006a). Thus, it is essential to find an optimum of dietary fiber that may decrease the risk of SARA without impairing important production performances in dairy cows.

However, assessment of dietary fiber adequacy in dairy cows from the current feed tables is difficult due to insufficient consideration of physical effectiveness of different feeds. For this reason, the concept of physically effective NDF (peNDF) proposed by Mertens (1997) is considered more efficient because it incorporates information on particle length and chemical NDF content of the diet. The latter 2 variables affect digesta stratification in the reticulorumen and rumination activity and, therefore, the ruminal buffering capacity and $\mathrm{pH}$ (Mertens, 1997; Zebeli et al., 2006a). The peNDF content of feeds or of TMR can be easily calculated even under on-farm conditions (Plaizier et al., 2004 ) by using the Penn State Particle Separator (Kononoff et al., 2003a). 
Although different studies conducted over the last decade provide important information into various physiological effects of peNDF in high-yielding dairy cows (e.g., Yang and Beauchemin, 2006a,b; 2007a,b), the optimum concentration of peNDF in dairy cow diets is uncertain. In fact, one of the drawbacks of the peNDF concept is that it does not take into consideration the differences in ruminal fermentability of various feedstuffs. Numerous studies (Allen, 1997; De Brabander et al., 2002; Zebeli et al., 2006b) reported that inclusion of rumen-fermentable $\mathrm{OM}$ or starch as a variable in the model together with dietary fiber, particle length index, or peNDF increases the accuracy of prediction of ruminal $\mathrm{pH}$ or milk fat content in dairy cows. The content of peNDF may interact with the content of rumen-fermentable carbohydrates and intake level and may modify the response of ruminal fermentation. The level of feed intake may determine important qualitative changes, particularly on passage and digestion kinetics in the reticulorumen (Firkins et al., 2001; Stone, 2004; Seo et al., 2006), which also may confound the response of ruminal $\mathrm{pH}$ to dietary peNDF.

Part of the difficulty in assessing adequacy of the dietary fiber and in determining peNDF requirements for dairy cows may also be related to the interpretation of the response of the ruminal $\mathrm{pH}$ and its resulting effects on fiber degradation or development of SARA. Ruminal $\mathrm{pH}$ in dairy cows is not constant, but fluctuates considerably in a $24-\mathrm{h}$ period. In high-yielding dairy cows fed high concentrate diets at $>45 \%$ of the ration (DM basis), ruminal $\mathrm{pH}$ generally ranges from 6.6 before morning feeding to 5.3 or 5.0 during the intensive rumen fermentation phases, with average $\mathrm{pH}$ typically at 6.0 or 6.1 . In fact, ruminal $\mathrm{pH}$ can drop below these average levels for considerable periods during the feeding cycle. Because the magnitude of diurnal fluctuations of ruminal $\mathrm{pH}$ has not been sufficiently characterized, the time of $\mathrm{pH}$ measurement may be misleading. Moreover, the rumen $\mathrm{pH}$ that defines SARA is still a matter of individual choice, with different researchers using different $\mathrm{pH}$ threshold values of 5.6 (Keunen et al., 2002), 5.8 (Beauchemin et al., 2003), or 6.0 (Krehbiel et al., 1995). The length of time per day when ruminal $\mathrm{pH}$ is under "suboptimal" levels (Beauchemin et al., 2003; Krause et al., 2003), or the index that weights the time spent under the optimal ruminal $\mathrm{pH}$ by the magnitude of the deviation from this $\mathrm{pH}$ (Mackie and Gilchrist, 1979), seem a better determinant of fiber degradation and presence of SARA than daily mean ruminal $\mathrm{pH}$, or the lowest (nadir) ruminal $\mathrm{pH}$ value Also, the time duration for which the ruminal $\mathrm{pH}$ must remain below this threshold value has not been properly defined.
The complexity of the interactions between feed intake, forage type, concentrate fed, and ruminal degradability of different feedstuffs as well as the uncertainty in defining the response of the ruminal $\mathrm{pH}$ make it difficult to quantitatively characterize the effects of peNDF on ruminal fermentation and prevention of SARA. These factors also hamper recommendations on optimal dietary peNDF levels for dairy cows. In this context, quantitative methods are helpful tools to synthesize knowledge and improve predictions of desired animal responses and support an optimal decision-making in formulating healthy diets for dairy cows (StPierre, 2001; Dijkstra et al., 2007).

The main objective of this study was to develop practical models to assess and predict the adequacy of dietary fiber in high-yielding dairy cows. Therefore, quantitative methods were used to analyze relevant research data and critically evaluate and determine the responses of ruminal $\mathrm{pH}$ and production performance to different variables including physical, chemical, and starch-degrading characteristics of the diet. Furthermore, extensive data were used to model the magnitude of ruminal $\mathrm{pH}$ fluctuations and determine the threshold for the development of SARA.

\section{MATERIALS AND METHODS}

\section{Responses of Ruminal $\mathrm{pH}$ and Production Performance to Diet Characteristics}

Description of Database. To define the responses of ruminal $\mathrm{pH}$ and production performance to physical and chemical characteristics of the diet, a database with data on animal performance, detailed ration components, and an evaluation of physical structure of the ration was generated. To evaluate the effects of dietary factors on production responses, data of feed intake, actual milk yield, 3.5\% FCM, milk fat yield, and milk energy efficiency (MEE) were considered. The MEE was calculated by dividing milk fat yield by DMI, and this was expressed as grams of milk fat produced per kilogram of DMI. This database was compiled from 58 studies containing a total of 238 treatment means, published mainly over the last $10 \mathrm{yr}$, and conducted with high-yielding dairy cows fed TMR. (A full list of references from studies included in this database is available in Table A1 of the appendix.) A statistical description of main characteristics of the database, including cow data, diet characteristics, and response variables are listed in Table 1. All studies used lactating Holstein cows $(95.5 \pm 48.4$ DIM; mean \pm SD) weighing between 528 and $886 \mathrm{~kg}$ and producing 18.1 to $49.3 \mathrm{~kg}$ of milk/ d (33.6 kg/d of 3.5\% FCM; Table 1). Milk fat content ranged from about 2.3 to $4.4 \%$, whereas the MEE averaged $51.8 \pm 7.57 \mathrm{~g} / \mathrm{kg}$ of DMI. The level of DMI averaged 
Table 1. Statistical description ${ }^{1}$ of cows, diet characteristics, and response variables included in the database used to model the responses of ruminal $\mathrm{pH}$ and milk production in dairy cows

\begin{tabular}{|c|c|c|c|c|c|c|c|c|c|}
\hline Item & \multicolumn{9}{|c|}{ Statistics } \\
\hline \multicolumn{10}{|l|}{ Cow data } \\
\hline DIM & 234 & 57 & 95.5 & 48.4 & 9.00 & 61.0 & 95.0 & 124 & 230 \\
\hline DMI, kg/d & 238 & 58 & 22.3 & 3.28 & 14.2 & 20.8 & 22.8 & 24.8 & 28.3 \\
\hline Milk protein, \% & 202 & 51 & 3.11 & 0.21 & 2.63 & 2.98 & 3.11 & 3.24 & 3.76 \\
\hline \multicolumn{10}{|l|}{ Diet characteristic, $\%$ of DM } \\
\hline $\mathrm{NDF}$ & 238 & 58 & 32.5 & 6.38 & 18.2 & 26.9 & 32.2 & 36.2 & 49.0 \\
\hline Forage NDF & 206 & 50 & 21.9 & 5.98 & 11.5 & 17.4 & 21.1 & 24.9 & 44.9 \\
\hline peNDF $^{2}$ & 187 & 45 & 24.1 & 7.10 & 4.24 & 20.5 & 24.1 & 29.1 & 40.6 \\
\hline $\mathrm{NFC}^{3}$ & 214 & 55 & 37.5 & 6.54 & 16.5 & 33.5 & 38.3 & 42.5 & 53.2 \\
\hline Starch from grains & 210 & 54 & 17.6 & 6.01 & 5.40 & 13.8 & 17.5 & 21.6 & 33.8 \\
\hline $\mathrm{RDSG}^{4}$ & 210 & 54 & 13.7 & 4.46 & 4.46 & 11.0 & 13.1 & 17.0 & 25.8 \\
\hline Starch from forages & 210 & 54 & 7.50 & 5.95 & 0.10 & 1.30 & 7.05 & 11.4 & 24.8 \\
\hline Ruminal pH (daily mean) & 205 & 54 & 6.10 & 0.26 & 5.30 & 5.95 & 6.07 & 6.28 & 6.73 \\
\hline $\mathrm{SE}$ of daily mean ruminal $\mathrm{pH}^{7}$ & 205 & 54 & 0.07 & 0.03 & 0.01 & 0.05 & 0.07 & 0.10 & 0.15 \\
\hline $\mathrm{VFA}, \mathrm{m} M$ & 196 & 50 & 116 & 19.2 & 74.9 & 101 & 117 & 129 & 162 \\
\hline Actual milk yield, $\mathrm{kg} / \mathrm{d}$ & 212 & 53 & 34.9 & 5.78 & 18.1 & 30.6 & 35.0 & 39.1 & 49.3 \\
\hline $3.5 \%$ FCM, kg/d & 212 & 53 & 33.6 & 5.94 & 22.2 & 29.0 & 33.0 & 37.8 & 49.0 \\
\hline Milk fat, $\%$ & 212 & 53 & 3.46 & 0.39 & 2.39 & 3.23 & 3.50 & 3.77 & 4.43 \\
\hline Milk fat yield, kg/d & 212 & 53 & 1.17 & 0.21 & 0.78 & 1.02 & 1.16 & 1.32 & 1.71 \\
\hline $\mathrm{MEE},{ }^{8} \mathrm{~g}$ of milk fat $/ \mathrm{kg}$ of DMI & 212 & 53 & 51.8 & 7.57 & 34.5 & 46.5 & 52.3 & 56.1 & 81.7 \\
\hline Total-tract NDF digestibility, $\%$ & 142 & 35 & 48.2 & 7.35 & 28.4 & 44.7 & 47.9 & 50.3 & 64.6 \\
\hline$k_{\mathrm{p}},{ }^{9} \% / \mathrm{h}$ & 140 & 34 & 4.06 & 1.40 & 1.90 & 2.99 & 3.78 & 4.59 & 8.40 \\
\hline
\end{tabular}

${ }^{1} \mathrm{n}_{\text {Treat }}=$ number of treatment means; $\mathrm{n}_{\text {Exp }}=$ number of experiments; $25_{\text {Perc }}=25$ th percentile; $75_{\text {Perc }}=75$ th percentile; a full list of references for studies included in this database is available in the appendix (Table A1).

${ }^{2}$ peNDF = physically effective NDF, measured as the NDF content of TMR multiplied by amount of DM particles retained on a 1.18-mm sieve (Mertens, 1997).

${ }^{3} \mathrm{NFC}$ calculated by $100-(\% \mathrm{CP}+\% \mathrm{NDF}+\%$ ether extract $+\%$ crude ash $)$.

${ }^{4} \mathrm{RDSG}=$ ruminally degradable starch from grain in TMR.

${ }^{5} \mathrm{RDSF}=$ ruminally degradable starch from forages in TMR.

${ }^{6} \mathrm{RDS}=$ ruminally degradable starch from both grains and forages in TMR.

${ }^{7}$ Standard error of the treatment mean reported from studies.

${ }^{8} \mathrm{MEE}=$ milk energy efficiency (expressed as g of milk fat produced per kg of DMI/d).

${ }^{9}$ Outflow rate of particulate digesta from reticulorumen, measured using external markers.

$22.3 \pm 3.28 \mathrm{~kg} / \mathrm{d}$ and the percentage of forage in TMR ranged from 26.8 to $80.8 \%$ of DM $(49.4 \pm 10.6 \%)$. Dietary NDF was from 18.2 to $49.0 \%$ of DM $(32.5 \pm 7.09 \%)$ and forage NDF (FNDF) between 11.5 and $44.9 \%$ of DM $(21.9 \pm 5.98 \%)$. Data on total-tract NDF digestibility and outflow rate of digesta from the reticulorumen $\left(\boldsymbol{k}_{\mathbf{p}}\right)$ were also included. Most of the studies included in this database recorded ruminal $\mathrm{pH}$ during $24 \mathrm{~h}$ either by using an indwelling electrode placed in the ventral rumen sac or by measuring $\mathrm{pH}$ from ruminal fluid in spot samples collected from the ventral sac of the rumen via rumen cannula. In some studies, ruminal $\mathrm{pH}$ was measured from spot fluid samples covering a time from shortly before to $12 \mathrm{~h}$ after morning feeding. In such cases, an average $\mathrm{pH}$ was calculated and considered as daily mean ruminal $\mathrm{pH}$ in this database. The $k_{\mathrm{p}}$ was measured using external markers (e.g., ytterbium, chromium). Overall, daily mean ruminal $\mathrm{pH}$ ranged from 5.30 to $6.73(6.10 \pm 0.26)$, NDF digestibility varied from 28.4 to $64.6 \%$, and $k_{\mathrm{p}}$ ranged from 1.9 to $8.4 \% / \mathrm{h}$. All studies were conducted in Latin square or double reversal designs and the sample size varied between 4 and 8 ruminally cannulated cows per study.

Measurement of peNDF of Diets. As a prerequisite for inclusion in this study, publications were expected to give complete information on the components and chemical composition of rations, as well as on the physical evaluation of experimental diets, using dry sieving techniques. The aim was to account for fiber and physical characteristics of the diet by including a measure- 
ment that included both NDF content and particle size (i.e., peNDF content) of the diet. The system proposed by Mertens (1997) for estimating peNDF based on NDF concentration of the diet multiplied by the proportion of particles retained on a $1.18-\mathrm{mm}$ sieve $\left(\mathbf{p e N D F} \mathbf{F}_{>\mathbf{1 . 1 8}}\right)$ using dry sieving techniques was used in the present study, because this measurement was previously shown to be a good indicator of physical characteristics of TMR in dairy cows (Mertens, 1997; Zebeli et al., 2006b). Thus, to measure peNDF $>1.18$ content of TMR in the present study, the DM proportion retained on a 1.18-mm sieve, obtained either through the vertical oscillating sieving technique or the new version of the Penn State Particle Separator (Kononoff et al., 2003a), was multiplied by NDF content (DM basis) of TMR. The differences in the content of peNDF $>1.18$ of the TMR between these 2 methods have been shown to be negligible, particularly when diets are based on forages other than corn silage (Yansari et al., 2004; Yang and Beauchemin, 2006b). For simplicity, hereafter in the text peNDF $>1.18$ will be simply presented as peNDF. As shown in Table 1, the peNDF content of TMR in this database was measured in 45 published studies with 187 treatment means, ranging from 4.2 to $40.6 \%$ of $\mathrm{DM}$ (on average $24.1 \pm$ $7.1 \%)$.

Estimation of Ruminally Degradable Starch from Grains and Forages in TMR. Because the concept of peNDF does not account for ruminal OM fermentability of TMR, rumen degradability of starch from different grains and forages composing the TMR was estimated and included in the analysis. This study focused on the effects of starch degradation rather than OM degradation, assuming that kinetics of starch degradation in the rumen is a more sensible variable for ruminal $\mathrm{pH}$ than $\mathrm{OM}$ degradation. The latter may be confounded by degradation characteristics of soluble and particularly insoluble cell wall components, which are shown to be very variable in the feedstuffs (Sauvant et al., 2004). In addition, OM degradation was shown not to be a proper indication of starch degradation, especially in barley grains (Ramsey et al., 2001).

Rumen degradability of starch from grains was estimated separately from that of forages to investigate the weight of each source of dietary starch on rumen fermentation and milk parameters. Rumen degradability of starch from different grains, including various by-products, was considered to take into account both the different starch amounts and differences in rumen degradability of starch among grain sources (e.g., barley vs. corn) in TMR, and physical or chemical treatments of grains (e.g., ground, dry rolled, steam-rolled, cracked, flaked, dry or high-moisture corn), which may modify their ruminal degradability. However, because of insignificant content in starch, the degradability character- istics of starch from soy products or other protein-rich concentrates was ignored in this analysis. Starch from forages was included in the analysis particularly to take into account those forage sources of TMR rich in starch, such as corn, oat, or barley silage.

All studies included in this database provided detailed information about the components of concentrate mixture and forage sources of TMR. Starch content of grains and forages either was taken direct from publications or was obtained from tables compiled by Sauvant et al. (2004). The effective ruminal degradability (ERD) of the starch from grains and forages was calculated from in situ degradation parameters $\left(\mathrm{a}, \mathrm{b}\right.$, and $k_{\mathrm{d}}$ ) of starch for different feedstuffs compiled by Offner et al. (2003), as follows:

$$
\mathrm{ERD}=\mathrm{a}+\mathrm{b} k_{\mathrm{d}} /\left(k_{\mathrm{d}}+k_{\mathrm{p}}\right)
$$

where $\mathrm{a}=$ soluble starch fractions $(\%) ; \mathrm{b}=$ slowly disappearing starch fractions $(\%) ; k_{\mathrm{d}}=$ fractional rate of disappearance of starch $(\% / \mathrm{h})$, and $k_{\mathrm{p}}=$ fractional passage rate of starch $(\% / \mathrm{h})$ from reticulorumen. The $k_{\mathrm{p}}$ was estimated using the equations of Seo et al. (2006) as shown below:

$$
\begin{gathered}
k_{\mathrm{p}} \text { for concentrates }(\% / \mathrm{h})=1.169+0.1375 \\
\times \mathrm{FpBW}+0.1721 \times \mathrm{CpBW} \\
k_{\mathrm{p}} \text { for forages }(\% / \mathrm{h})=2.365+0.0214 \\
\times \mathrm{FpBW}+0.0734 \times \mathrm{CpBW}+0.069 \times \mathrm{FDMI}
\end{gathered}
$$

where FpBW = forage DMI as the proportion of BW (g/ $\mathrm{kg} \mathrm{BW}), \mathrm{CpBW}=$ concentrate DMI as the proportion of BW $(\mathrm{g} / \mathrm{kg}$ of BW), and FDMI = forage DMI $(\mathrm{kg})$.

Subsequently, the content of ruminally degradable starch of concentrate mixture (RDSG) was calculated according to the formula:

$$
R D S G=\sum_{i=1}^{n} p_{i} \times E R D_{i}
$$

where $p_{\mathrm{i}}$ represents the proportion of dietary starch provided from grain $i$ in the concentrate mixture, and $E R D_{\mathrm{i}}$ represents starch effective degradability for grain $i$, and $n$ is the number of grains in the concentrate mixture of TMR. The formula [4] was also used to calculate the content of ruminally degradable starch from forages (RDSF) in TMR. The total content of degradable starch in the diet was calculated as the sum of RDSG and RDSF and was also included as a variable in the analysis. 
Table 2. Statistical description ${ }^{1}$ of the database used to characterize the relationship between daily mean and fluctuation of ruminal $\mathrm{pH}$

\begin{tabular}{lccccccccc}
\hline & \multicolumn{10}{c}{ Statistics } \\
\cline { 2 - 9 } Item & $\mathrm{n}_{\text {Treat }}$ & $\mathrm{n}_{\operatorname{Exp}}$ & Mean & $\mathrm{SD}$ & Minimum & $25_{\text {Perc }}$ & Median & $75_{\text {Perc }}$ & Maximum \\
\hline Ruminal pH (daily mean) & 326 & 80 & 6.09 & 0.27 & 5.49 & 5.93 & 6.09 & 6.25 & 6.72 \\
SE of daily mean ruminal $\mathrm{pH}^{2}$ & 326 & 80 & 0.08 & 0.06 & 0.01 & 0.05 & 0.07 & 0.10 & 0.40 \\
Time pH <5.8, h & 326 & 80 & 5.74 & 1.94 & 0.00 & 3.72 & 5.90 & 9.13 & 19.6 \\
Lowest ruminal pH & 191 & 49 & 5.50 & 0.29 & 4.80 & 5.27 & 5.47 & 5.71 & 6.44 \\
SE of lowest ruminal $\mathrm{pH}^{2}$ & 191 & 49 & 0.11 & 0.13 & 0.01 & 0.07 & 0.09 & 0.12 & 1.07 \\
\hline
\end{tabular}

\footnotetext{
${ }^{1} \mathrm{n}_{\text {Treat }}=$ number of treatment means; $\mathrm{n}_{\text {Exp }}=$ number of experiments; $25_{\text {Perc }}=25$ th percentile; $75_{\text {Perc }}=75$ th percentile; a full list of references for the studies included in this database is available in the appendix (Table A2).

${ }^{2}$ Standard error of the treatment mean reported from studies.
}

\section{Characterization of Ruminal pH Fluctuation and SARA Challenge}

To characterize the magnitude of ruminal $\mathrm{pH}$ fluctuation (i.e., relationships between daily mean and time length of $\mathrm{pH}$ below 5.8 , or the lowest ruminal $\mathrm{pH}$ ) throughout the day, another database containing a total of 326 treatment means was generated from 80 studies conducted with dairy cows and steers and published from 1991 to 2007. (A full list of references included in this database is shown in Table A2 of the appendix.) This database was focused only on studies reporting ruminal $\mathrm{pH}$ both as daily mean and duration of time with $\mathrm{pH}<5.8$. Daily mean ruminal $\mathrm{pH}$ of this database ranged from 5.49 to $6.72(6.09 \pm 0.27)$, time length of $\mathrm{pH}<5.8$ ranged from 0.0 to $19 \mathrm{~h} / \mathrm{d}$ (average $5.74 \pm 1.94 \mathrm{~h} / \mathrm{d}$ ), and the lowest ruminal $\mathrm{pH}$ varied between 4.80 and 6.44 (Table 2).

Ruminal $\mathrm{pH}$ of 5.8 was considered detrimental for rumen function, below which fiber digestion by the rumen microorganisms is suboptimal, and as a threshold for the development of SARA in dairy cows (Beauchemin et al., 2003; Yang and Beauchemin, 2007a). However, it was assumed that the effects of ruminal $\mathrm{pH}$ on rumen function or SARA development depend on the duration of time in which $\mathrm{pH}$ remains below 5.8. To define ruminal $\mathrm{pH}$ (both in terms of daily mean and duration of time of $\mathrm{pH}<5.8$ ) in dairy cows with challenging SARA or not, results of 20 experiments from 17 recent published studies were summarized in a database. (A full list of references included in this database is shown in Table A3 in the appendix.) In these studies, SARA was experimentally induced and monitored in dairy cows (17 experiments) and steers (3 experiments). These studies recorded ruminal $\mathrm{pH}$ over $24 \mathrm{~h}$ for several days and reported both daily mean ruminal $\mathrm{pH}$ and time length of $\mathrm{pH}$ below 5.6 and 6.0 or below 5.8. If not directly reported from studies, the duration of time of ruminal $\mathrm{pH}$ below 5.8 was calculated as an average from time length of $\mathrm{pH}$ below 5.6 and 6.0 .

\section{Analysis of Data}

Ruminal pH Response to Dietary Factors. To evaluate and model the response of ruminal $\mathrm{pH}$ and milk parameters to dietary factors, the data generated from 58 studies with high-yielding dairy cows with a total of 238 dietary treatment means were subjected to mixed model analysis using PROC MIXED (SAS Institute, 2003), considering the random effect of the study (St-Pierre, 2001), as shown below:

$$
\mathrm{Y}_{i j}=\alpha_{0}+\beta_{1} \mathrm{X}_{i j}+\mathrm{s}_{i}+\mathrm{b}_{i} \mathrm{X}_{i j}+\mathrm{e}_{i j}
$$

where $\mathrm{Y}_{i j}=$ the expected outcome for the dependent variable $\mathrm{Y}$ (i.e., response of ruminal $\mathrm{pH}$ or milk parameters being modeled) observed at level $j(j=2, \ldots, \mathrm{n})$ of the predictor variable $\mathrm{X}$ (dietary factor) in the study $i ; n$ is the number of treatment means in study $i ; \alpha_{0}=$ the overall intercept across all studies (fixed effect); $\beta_{1}=$ the overall regression coefficient of $\mathrm{Y}$ on $\mathrm{X}$ across all studies (fixed effect); $\mathrm{X}_{i j}=$ the value $j$ of continuous variable $\mathrm{X}$ in study $i ; \mathrm{s}_{i}=$ the random effect of the study $i(i=1, \ldots, 58) ; \mathrm{b}_{i}=$ the random effect of study $i$ on the regression coefficient of $\mathrm{Y}$ on $\mathrm{X}$ in study $i$, and $\mathrm{e}_{i j}=$ the unexplained error. Thus, the random effect components of the model include $s_{i}+b_{i} X_{i j}+e_{i j}$, and the distributions are shown below:

$$
e_{i j} \sim i i d N\left(0, \sigma_{\mathrm{e}}^{2}\right) \text { and }\left[\begin{array}{l}
s_{i} \\
b_{i}
\end{array}\right] \sim i i d N\left[\left(\frac{0}{0}\right), \Sigma\right] \text {, }
$$

which assumes that $e_{i j}$ is normally distributed with a mean of 0 and constant variance, and that $s_{i}$ and $b_{i}$ are normally distributed, have means of 0 , and $\Sigma$ is their variance-covariance matrix: 


$$
\Sigma=\left[\begin{array}{cc}
\sigma_{s}^{2} & \sigma_{s b} \\
\sigma_{s b} & \sigma_{b}^{2}
\end{array}\right]
$$

An unstructured variance-covariance structure matrix $($ TYPE $=\mathrm{UN}$ ) was adopted to avoid the positive correlation between the intercepts and slopes, as suggested by St-Pierre (2001). To take the unequal variance among studies into consideration, the dependent variable was weighted by the reciprocal of its squared SE (SE of treatment means were taken directly from studies). When a dietary factor was significant $(P<$ 0.05 ), its squared term was included in the model to test any quadratic relationship. In this case, the variance-covariance matrix was modeled as variance components $(\mathrm{TYPE}=\mathrm{VC}$ ) to assure the convergence. After a visual inspection of the data using PROC GPLOT (SAS Institute, 2003), daily mean ruminal $\mathrm{pH}$ response to dietary peNDF was modeled as a linear-plateau using PROC NLIN (SAS, 2003; method = Marquardt), as shown below:

$$
\mathrm{Y}= \begin{cases}\mathrm{a}+\mathrm{b} \times x & \text { if } x<x_{0} \\ \mathrm{a}+\mathrm{b} \times x_{0} & \text { if } x \geq x_{0}\end{cases}
$$

where $\mathrm{Y}$ is daily mean ruminal $\mathrm{pH}, a$ is the intercept, $b$ is the slope (of the linear portion of the model), $x$ is dietary peNDF, and $x_{0}$ is the break-point (the point beyond which there is no significant change of $\mathrm{Y}$ ). Because of a better fitting, the response of DMI and milk parameters to dietary peNDF was modeled using the broken-line regression technique (i.e., single- or double-breakpoint models; Robbins et al., 2006) with PROC NLIN (SAS Institute, 2003; method = Marquardt), as shown below:

$$
\begin{gathered}
\mathrm{Y}= \\
\left\{\begin{array}{l}
\mathrm{a}+\mathrm{b}_{1} \times x \quad \text { if } x \leq \mathrm{R}_{1} \\
\mathrm{a}+\mathrm{b}_{1} \times \mathrm{R}_{1}+\mathrm{b}_{2} \times\left(x-\mathrm{R}_{1}\right) \quad \text { if } \mathrm{R}_{2} \geq x>\mathrm{R}_{1} \\
\mathrm{a}+\mathrm{b}_{1} \times \mathrm{R}_{1}+\mathrm{b}_{2} \times\left(\mathrm{R}_{2}-\mathrm{R}_{1}\right)+\mathrm{b}_{3} \times\left(x-\mathrm{R}_{2}\right)
\end{array}\right.
\end{gathered}
$$

where $\mathrm{Y}$ is the response variable, $a$ is the general intercept, $b_{1}, b_{2}$, and $b_{3}$ are the slopes for the first, second, and third straight-line segment, respectively, $x$ is dietary peNDF, and $R_{1}$ and $R_{2}$ are the first and second breakpoints, respectively. Root mean square error (RMSE) and determination coefficient $\left(\mathrm{R}^{2}\right)$ were subsequently computed and used to evaluate the goodness of fit.

Further, all significant dietary factors $(P<0.05)$ were also tested together using the backward elimination technique, similar to the algorithm reported by Firkins et al. (2001). In this case, to limit model over- parameterization, a variance inflation factor less than 10 (which assumes no significant multicollinearity among predictor variables tested) for every continuous independent variable tested was assumed (Neter et al., 1996).

Ruminal pH Fluctuation and Threshold of SARA. To characterize the relationship between time length of ruminal $\mathrm{pH}<5.8$ and daily mean ruminal $\mathrm{pH}$, data obtained from observations as summarized in Table 2 were used. The statistical rationale used was the same as model [5], only that the response variable was the time length of $\mathrm{pH}<5.8$, and daily mean ruminal $\mathrm{pH}$ was used as a predictor variable. Random effect of study was also considered, and to take into consideration the unequal variance among studies, the dependent variable was weighted by the reciprocal of its squared SE, which can improve the overall precision and ensure homogeneity of variance for the model (St-Pierre, 2001). Relationship between the lowest $\mathrm{pH}$ and the daily mean ruminal $\mathrm{pH}$ was tested using PROC CORR (SAS Institute, 2003). After a visual inspection of the data using PROC GPLOT (SAS Institute, 2003), time length of $\mathrm{pH}<5.8$ response to daily mean ruminal $\mathrm{pH}$ was modeled as a linearplateau using PROC NLIN (SAS Institute, 2003; method $=$ Marquardt), as indicated by model [6] .

As previously mentioned, data summarized from 20 experiments, which were conducted to experimentally induce and characterize SARA, were used to determine cut-off points of ruminal $\mathrm{pH}$ (i.e., daily mean and diurnal time of $\mathrm{pH}$ remaining below 5.8 per day) for cows with challenged SARA conditions. The least-squares means and confidence intervals (CI; 95 and 99\%) were calculated using PROC GLIMMIX (SAS Institute, 2003) with a lognormal distribution function (DIST= LOGNORMAL), which is reported as appropriate to analyze data from small samples under moderate nonnormality (Douglas, 2006). Confidence intervals give a range of plausible values for the true ruminal $\mathrm{pH}$ characterizing SARA or normal ruminal fermentation. For estimation of parameters, the pseudo-likelihood method was used, whereas degrees of freedom were approximated using Satterthwaite's method. To account for differences among studies, the random effect of the experiment was considered in the analysis.

Evaluation of Dietary Fiber Adequacy. An Excel (Microsoft Office, version 2003) spreadsheet version was built from the previously mentioned model, which predicts the ruminal $\mathrm{pH}$ response to multiple dietary factors, to allow changes in the running parameters of this model. Subsequently, this spreadsheet was linked to RiskAMP version 2.65 (Structured Data LLC, New York, NY), a software program that works by a Monte Carlo simulation engine, to run stochastic 
simulations, as described by Zebeli and Drochner (2007). Monte Carlo stochastic simulations were performed to evaluate the risk of occurrence of the time length of $\mathrm{pH}<5.8$ when apparently adequate levels of peNDF were offered (i.e., adequate peNDF level was previously estimated), but differing in RDSG content and DMI level. The PERT distribution was used to generate the stochastic variables characterizing the variation of ruminal $\mathrm{pH}$ response to dietary scenarios tested, where minimum and maximum values were included based on empirical observations reported from published studies and summarized in the database, and the most likely estimates were obtained as a product of the predictions from the model. The PERT distribution is a special case of the beta distribution that uses the parameters (i.e., minimum, maximum, and most likely) to create a smooth curve that fits well to the normal or lognormal distributions (Vose, 2000). The description of probability density function of PERT distribution is given below:

$$
f(x)=\frac{1}{B\left(\alpha_{1},-\alpha_{2}\right)} \frac{(x-a)^{\alpha_{1}-1}(b-x)^{\alpha_{2}-1}}{(b-a)^{\alpha_{1}+\alpha_{2}-1}}
$$

where $a$ and $b$ are the boundary parameters of the stochastic variable $x(\mathrm{a}<\mathrm{b}), m$ is the most likely value of $x(\mathrm{a} \leq \mathrm{m} \leq \mathrm{b})$, and $\alpha_{1}$ and $\alpha_{2}$ are parameters describing the shape of the curve.

$$
\alpha_{1}=\frac{4 m+b-5 \mathrm{a}}{\mathrm{b}-\mathrm{a}} \text { and } \alpha_{2}=\frac{5 b-a-4 \mathrm{~m}}{\mathrm{~b}-\mathrm{a}} .
$$

Outputs of the analysis (i.e., the probabilities of occurrence of any duration time of $\mathrm{pH}$ below 5.8) are shown in the form of cumulative distribution functions (CDF). Cumulative distribution functions of the stochastic variable $\times\left[\mathrm{F}_{\mathrm{x}}(x)\right]$ is the probability that this variable, having a probability density function of $\mathrm{f}_{\mathrm{X}}(x)$, takes on a value less than or equal to $x$ (Vose, 2000), and is expressed as follows:

$$
\begin{gathered}
\mathrm{F}_{\mathrm{X}}(x)=\mathrm{P}(\mathrm{X} \leq x)= \\
\mathrm{P}(-\infty \leq \mathrm{X} \leq x)=\int_{-\infty}^{x} f x(X) d x .
\end{gathered}
$$

A sufficiently large number of simulation iterations were run $(10,000)$, so that the CDF were adequately described (Isukapalli et al., 1998).

\section{RESULTS}

\section{Diurnal Fluctuations of Ruminal $\mathrm{pH}$ and SARA}

The model characterizing the relationship between duration of time for ruminal $\mathrm{pH}<5.8$ and daily mean

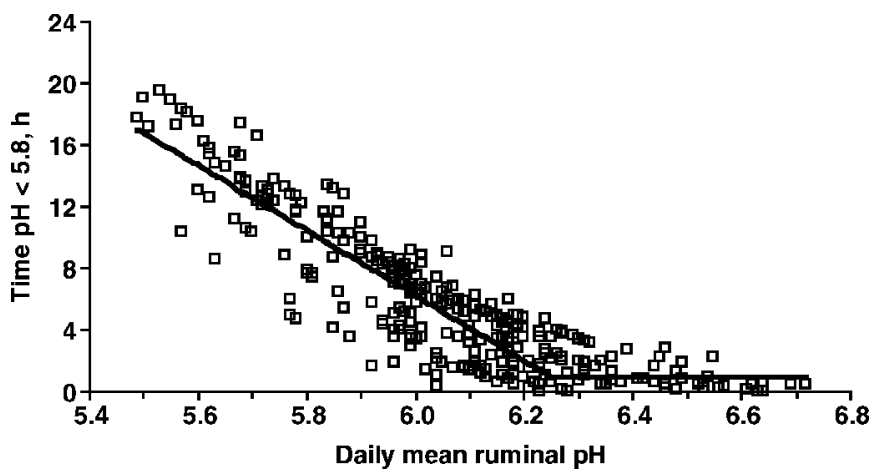

Figure 1. Model showing the relationship between time of ruminal $\mathrm{pH}$ remaining below 5.8 per day $(\mathrm{Y})$ and daily mean ruminal $\mathrm{pH}(\mathrm{X})$ : $\mathrm{Y}=5.59( \pm 0.031)+0.0218( \pm 0.002) \times \mathrm{X}$, when $\mathrm{X}<6.25 \pm 0.02$, (estimate $\pm \mathrm{SE}$ ), asymptotic plateau of $\mathrm{Y}=0.97 \mathrm{~h} / \mathrm{d}$; root mean square error $=1.7 \mathrm{~h} / \mathrm{d}, \mathrm{R}^{2}=0.88$, number of experiments $=80$, number of treatment means $=326$.

ruminal $\mathrm{pH}$ is shown in Figure 1. The duration of time for ruminal $\mathrm{pH}<5.8$ was negatively correlated to daily mean ruminal $\mathrm{pH}\left(\mathrm{R}^{2}=0.88\right)$. The linear-plateau model revealed that the break-point of daily mean ruminal $\mathrm{pH}$ is reached at $6.25 \pm 0.02$, which corresponded to an asymptotic plateau of about $1 \mathrm{~h} / \mathrm{d}$ for the time length of $\mathrm{pH}<5.8$. The lowest (nadir) $\mathrm{pH}$ correlated positively to daily mean ruminal $\mathrm{pH}$ according to the following equation:

$$
\begin{gathered}
\text { Daily mean ruminal } \mathrm{pH}=1.92( \pm 0.163) \\
+0.745( \pm 0.029) \times \text { nadir } \mathrm{pH} \\
\mathrm{RMSE}=0.12, \mathrm{r}=0.89 ; P<0.001
\end{gathered}
$$

The least squares means and CI for daily mean and time length of ruminal $\mathrm{pH}<5.8$ in cows with challenged SARA or that experienced normal fermentation are given in Table 3. This analysis showed that, with $99 \%$ likelihood, the true values of daily mean $\mathrm{pH}$ and time length of ruminal $\mathrm{pH}<5.8$ for cows with challenged SARA lie between 5.82 and 6.14 , or within the range from 5.47 to $15.54 \mathrm{~h} / \mathrm{d}$, respectively (i.e., lower and upper bound of $99 \% \mathrm{CI}$ ). In contrast, with $99 \%$ likelihood, this data analysis revealed that cows may not experience SARA if daily mean ruminal $\mathrm{pH}$ is higher than 6.16 or the time in which ruminal $\mathrm{pH}$ is below 5.8 does not exceed $5.24 \mathrm{~h} / \mathrm{d}$ (i.e., lower bound of $99 \%$ $\mathrm{CI}$ for daily mean $\mathrm{pH}$ and upper bound of $99 \% \mathrm{CI}$ for time of $\mathrm{pH}<5.8$ showing no SARA conditions, respectively).

\section{Response of Ruminal pH to Dietary Factors and Fiber Digestibility}

Results showing the response of daily mean ruminal $\mathrm{pH}$ to some individual dietary factors (only factors sig- 
Table 3. Least squares means (LSmeans) and confidence intervals (CI; lower and upper bound of 95 and $99 \% \mathrm{CI}$ ) of ruminal $\mathrm{pH}$ (i.e., daily mean and time of $\mathrm{pH}$ below 5.8) from cows challenging subacute ruminal acidosis (SARA) or experiencing normal fermentation (control) ${ }^{1}$

\begin{tabular}{|c|c|c|c|c|c|c|}
\hline \multirow[b]{2}{*}{ Measurement of ruminal $\mathrm{pH}$} & \multirow[b]{2}{*}{ Treatment } & \multirow[b]{2}{*}{ LSmeans } & \multicolumn{2}{|c|}{$95 \% \mathrm{CI}$} & \multicolumn{2}{|c|}{$99 \% \mathrm{CI}$} \\
\hline & & & Lower & Upper & Lower & Upper \\
\hline \multirow[t]{2}{*}{ Daily mean $\mathrm{pH}$} & SARA & 5.98 & 5.87 & 6.09 & 5.82 & 6.14 \\
\hline & Control & 6.32 & 6.21 & 6.44 & 6.16 & 6.49 \\
\hline \multirow[t]{2}{*}{ Time of $\mathrm{pH}<5.8, \mathrm{~h} / \mathrm{d}$} & SARA & 9.02 & 6.29 & 13.2 & 5.47 & 15.5 \\
\hline & Control & 2.98 & 1.98 & 4.49 & 1.62 & 5.24 \\
\hline
\end{tabular}

${ }^{1}$ For calculations data were used stemming from experiments in which SARA was induced and monitored experimentally; a full list of references for the studies used is available in Table A3 of the appendix.

nificantly affecting ruminal $\mathrm{pH}$ ) are shown in Table 4. Ruminal $\mathrm{pH}$ was positively affected by NDF and FNDF, and negatively by NFC, NFC:NDF ratio, and RDSG in the diet. The model showing the relationship between daily mean ruminal $\mathrm{pH}$ and dietary peNDF is shown in Figure 2. Increasing dietary peNDF up to $31.2 \pm 1.6 \%$ (DM basis) significantly increased ruminal $\mathrm{pH}$, of which the asymptotic plateau was achieved at a $\mathrm{pH}$ of 6.27. Also the peNDF:RDSG ratio significantly affected ruminal $\mathrm{pH}$. As shown in Table 4, increasing peNDF:RDSG ratio in the diet increased ruminal $\mathrm{pH}$ in a curvilinear fashion. Hence, ruminal $\mathrm{pH}$ was found to plateau at 6.20 in response to a ratio of $1.45 \pm 0.22$ of peNDF to RDSG in the diet.

The analysis of backward elimination showed that inclusion of more dietary factors in the same model increased the accuracy of prediction of ruminal $\mathrm{pH}$ response compared with the models when only individual factors were separately tested (Table 5). Thus, this analysis indicated that ruminal $\mathrm{pH}$ may increase $\left(\mathrm{R}^{2}=\right.$ $0.65 ; P<0.001$ ) when dietary peNDF (quadratically)

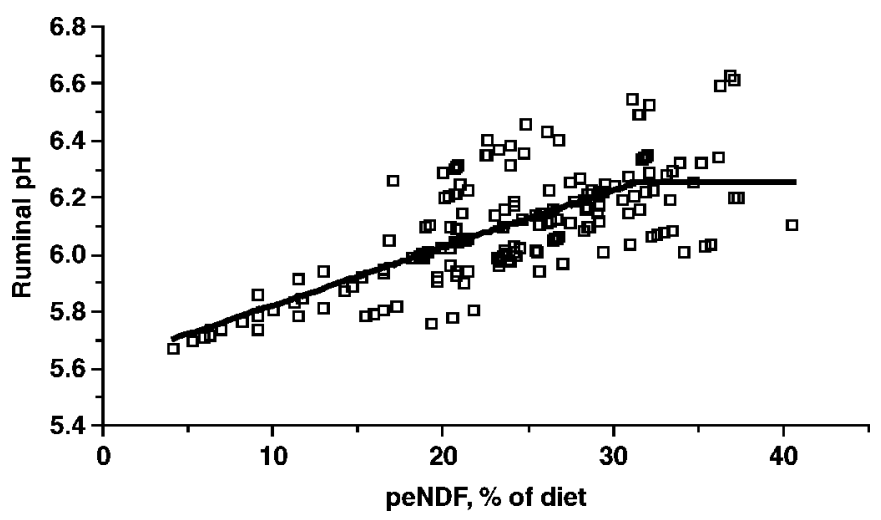

Figure 2. Model showing the relationship between daily mean ruminal $\mathrm{pH}$ and dietary physically effective NDF (peNDF) in highyielding dairy cows: ruminal $\mathrm{pH}=5.59( \pm 0.031)+0.0218( \pm 0.002)$ $\times$ peNDF, when peNDF $<31.2 \pm 1.60 \%$ (estimate $\pm \mathrm{SE}$ ), asymptotic plateau of $\mathrm{pH} 6.27$; root mean square error $=0.14, \mathrm{R}^{2}=0.50$, number of experiments $=45$, number of treatment means $=187$. increases, and both RDSG and DMI (linearly) decrease.

Figure 3 shows the CDF for the occurrence of any duration time of ruminal $\mathrm{pH}<5.8$ resulting from variation of ruminal $\mathrm{pH}$ response when diets were simulated with constant, though apparently adequate peNDF levels (i.e., $31.2 \%$ in DM), but differing in the content of RDSG (i.e., 14 and $22 \%$ in DM) and amount of DM consumed (i.e., 20 and $25 \mathrm{~kg} \mathrm{DM} / \mathrm{d}$ ). A low CDF indicates a lower risk of occurrence of any certain time length of ruminal $\mathrm{pH}<5.8$, and conversely, a higher CDF indicates a high risk of occurrence. Overall, data showed that increasing RDSG in the diet from 14 to $22 \%$ and DMI from 20 to $25 \mathrm{~kg} / \mathrm{d}$ increased the risk of occurrence of any length of time of ruminal $\mathrm{pH}<5.8$, despite the similar peNDF content.

This study also showed that digestibility of NDF in the total digestive tract depends on ruminal $\mathrm{pH}$ and $k_{\mathrm{p}}$; therefore, both variables explained $62 \%$ of the variation of NDF digestibility. Hence, NDF digestibility increased linearly with increasing ruminal $\mathrm{pH}$, decreasing $k_{\mathrm{p}}(\% / \mathrm{h})$, or both, according to the following equation:

$$
\begin{gathered}
\text { NDF digestibility }(\%)=-32.24( \pm 15.25) \\
+14.91( \pm 2.38) \text { ruminal } \mathrm{pH}-2.54( \pm 0.42) k_{\mathrm{p}} \\
\mathrm{RMSE}=0.68, \mathrm{R}^{2}=0.62
\end{gathered}
$$

\section{Response of Feed Intake and Milk Parameters}

Relationship between DMI and dietary peNDF was low in this study $\left(\mathrm{RSME}=3.03 \mathrm{~kg} \mathrm{DM} / \mathrm{d} ; \mathrm{R}^{2}=0.18\right.$; Figure 4). The broken-line model revealed that DMI tended to increase with increasing peNDF content up to $21.6 \pm 2.92 \%$ in TMR. Further, when feeding a diet with a peNDF content ranging from 21.6 to $31.9 \pm$ $1.97 \%$, the model showed that DMI slightly declined (slope: $-0.245 \pm 0.122$; Figure 4). However, when diets exceeded the latter content of peNDF, a higher depres- 
Table 4. Equations showing the response of ruminal $\mathrm{pH}$ to different dietary factors in dairy cows ${ }^{1}$

\begin{tabular}{|c|c|c|c|c|c|c|}
\hline \multirow[b]{2}{*}{ Dietary factor ${ }^{2}$} & \multicolumn{4}{|c|}{ Parameter estimates } & \multicolumn{2}{|c|}{ Model statistics $^{3}$} \\
\hline & Intercept & $\mathrm{SE}_{\text {Intercept }}$ & Slope & $\mathrm{SE}_{\text {Slope }}$ & RMSE & $\mathrm{R}^{2}$ \\
\hline $\mathrm{NDF}, \%$ of $\mathrm{DM}$ & 5.45 & 0.07 & 0.019 & 0.001 & 0.16 & 0.37 \\
\hline Forage NDF, $\%$ of DM & 5.61 & 0.05 & 0.020 & 0.002 & 0.15 & 0.41 \\
\hline $\mathrm{NFC}, \%$ of $\mathrm{DM}$ & 6.35 & 0.08 & -0.008 & 0.002 & 0.15 & 0.12 \\
\hline NFC:NDF & 6.36 & 0.04 & -0.256 & 0.029 & 0.17 & 0.28 \\
\hline RDSG, \% of DM & 6.37 & 0.03 & -0.020 & 0.001 & 0.13 & 0.34 \\
\hline peNDF:RDSG ${ }^{4}$ & 5.53 & 0.03 & 0.449 & 0.016 & 0.15 & 0.41 \\
\hline
\end{tabular}

\footnotetext{
${ }^{1}$ Only significant relationships are shown $(P<0.05)$.

${ }^{2} \mathrm{NFC}$ calculated by $100-(\% \mathrm{CP}+\% \mathrm{NDF}+\%$ ether extract $+\%$ crude ash $) ;$ RDSG $=$ ruminally degradable starch from grains of TMR; peNDF = physically effective NDF, measured as the NDF content of TMR multiplied by amount of DM particles retained on a 1.18-mm sieve (Mertens, 1997).

${ }^{3} \mathrm{RMSE}=$ root mean square error.

${ }^{4}$ Relationship was nonlinear: breakpoint for peNDF:RDSG ratio $=1.45 \pm 0.22$, asymptotic plateau of ruminal $\mathrm{pH}=6.20$.
}

sion of DMI was estimated (slope: $-0.897 \pm 0.349$; Figure 4).

Effects of peNDF and other dietary factors on milk parameters are shown in Figure 5 and Table 6. Milk yield was increased with increasing DMI and RDSF content in the diet (Table 6). In contrast, the model showed that dietary peNDF had a poor, though negative effect (slope: $-0.174 \pm 0.237$ ) on actual milk yield in this study $\left(\mathrm{RSME}=6.1 \mathrm{~kg} \mathrm{milk} / \mathrm{d} ; \mathrm{R}^{2}=0.09\right.$, result not shown), particularly when peNDF content in the diet was lower than an average of $32.0 \pm 1.85 \%$. When exceeding the latter average content of peNDF, the decline in milk yield was higher (slope: $-1.486 \pm 0.677$, result not shown).

As shown in Figure 5A, peNDF content in the diet positively affected milk fat content, particularly beginning with a dietary peNDF content of about $20 \pm 3.2 \%$. This was reflected in a higher MEE, particularly by increasing peNDF content in the diet from 17.1 to $32.4 \%$ (Figure 5B). After this, the MEE was reduced (slope: $-1.14 \pm 0.847)$, although milk fat content linearly increased (Figure 5A,B). In general, the backward elimi-

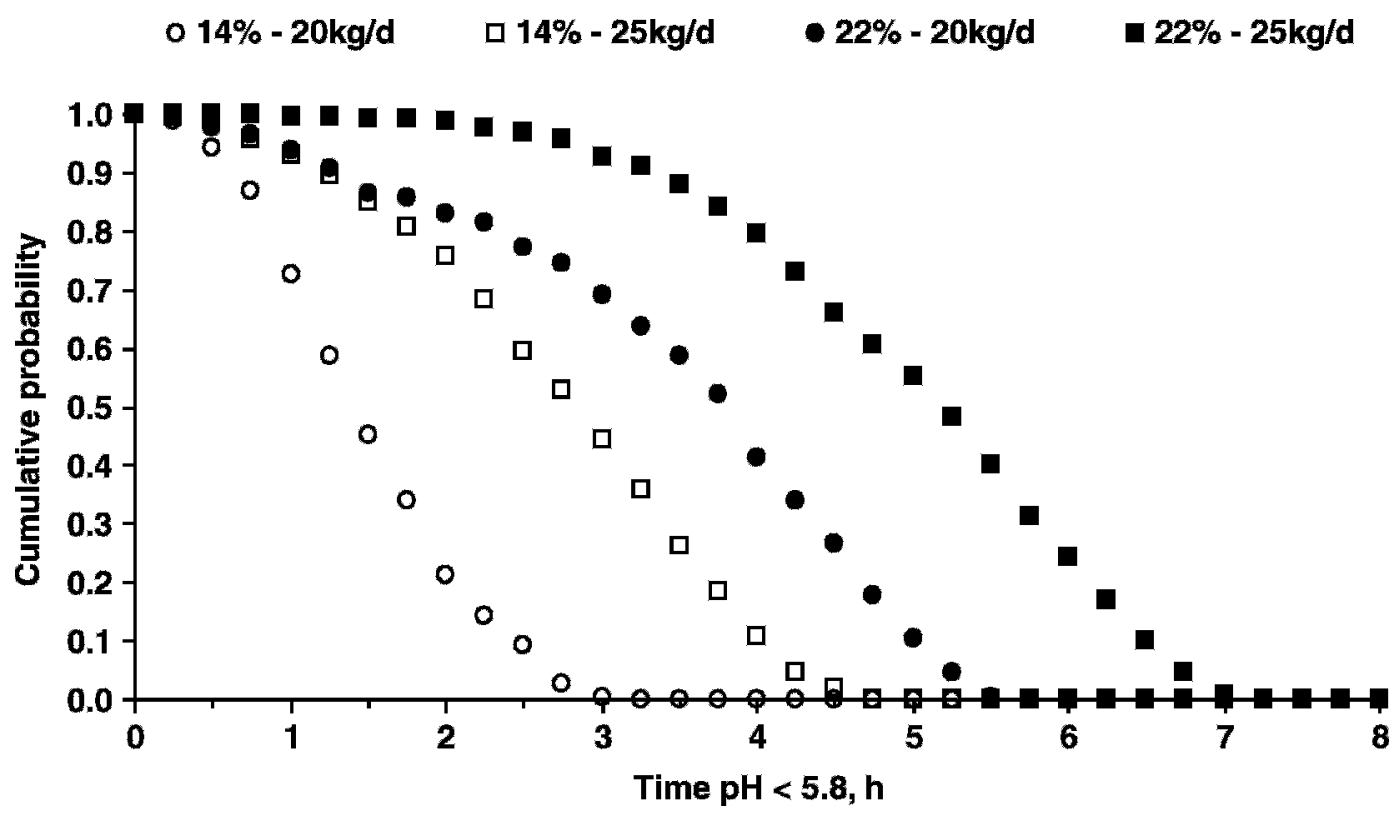

Figure 3. Cumulative probability distribution showing the risk of occurrence of any duration time of ruminal pH below 5.8 when simulations were performed for cows fed diets containing constant physically effective NDF (31.2\% in DM), but differing in ruminally degradable starch from grains in TMR (14 and $22 \%$ in DM) and levels of DMI (20 and $25 \mathrm{~kg}$ of DM/d). 
Table 5. Best-fit equation showing the response of ruminal $\mathrm{pH}$ to different dietary factors using backward elimination technique

\begin{tabular}{|c|c|c|c|c|c|c|c|c|}
\hline \multirow[b]{2}{*}{ Dietary factor ${ }^{1}$} & \multicolumn{4}{|c|}{ Parameter estimates } & \multicolumn{4}{|c|}{ Model statistics ${ }^{2}$} \\
\hline & Intercept & $\mathrm{SE}_{\text {Intercept }}$ & Slope & $\mathrm{SE}_{\text {Slope }}$ & RMSE & $\mathrm{R}^{2}$ & VIF & $P=$ \\
\hline peNDF, \% of DM & 6.05 & 0.115 & 0.044 & 0.0069 & 0.11 & 0.66 & 5.99 & $<0.001$ \\
\hline peNDF $^{2}, \%$ of DM & - & - & -0.0006 & 0.0001 & - & - & 8.97 & $<0.001$ \\
\hline RDSG, \% of DM & - & - & -0.017 & 0.0026 & - & - & 2.41 & $<0.001$ \\
\hline DMI, kg/d & - & - & -0.016 & 0.0034 & - & - & 1.24 & $<0.001$ \\
\hline
\end{tabular}

${ }^{1}$ peNDF $=$ physically effective NDF, measured as the NDF content of TMR multiplied by amount of DM particles retained on a 1.18-mm sieve (Mertens, 1997); RDSG = ruminally degradable starch from grains of TMR.

${ }^{2} \mathrm{RMSE}=$ root mean square error; $\mathrm{VIF}=$ variance inflation factor $(\mathrm{VIF}<10$ is assumed to show no significant multicollinearity among predictor variables).

nation procedure revealed that milk fat yield and FCM were positively affected by peNDF content and DMI and negatively by RDSG and DIM (Table 6).

\section{DISCUSSION}

\section{Diurnal Fluctuations of Ruminal $\mathrm{pH}$ and SARA}

Data analyzed to characterize the diurnal fluctuations of ruminal $\mathrm{pH}$ showed that cows spent several hours per day in which ruminal $\mathrm{pH}$ remained $<5.8$. One finding of this study was that this time length could be characterized with reasonable accuracy from the daily mean ruminal $\mathrm{pH}$, whereby the latter can be estimated from nadir value of the ruminal $\mathrm{pH}$. In fact, the precise time when the nadir of ruminal $\mathrm{pH}$ occurs could not be evaluated in this study. However, assuming that this nadir is reached at 10 to $14 \mathrm{~h}$ after the morning feeding in dairy cows fed high concentrate diets ad libitum (Krause and Oetzel, 2005; Tafaj et al., 2005; Yang and Beauchemin, 2007a), it is possible that by using this measurement, both daily mean ruminal $\mathrm{pH}$ and the time length of $\mathrm{pH}<5.8$ can be assessed through the relationships established for these variables in this study.

The present study showed that a break-point for the time length of the ruminal $\mathrm{pH}<5.8$ was reached when the daily mean $\mathrm{pH}$ value was $6.25 \pm 0.02$. The latter corresponded to an asymptotic plateau of $1 \mathrm{~h}$ for the time length of $\mathrm{pH}<5.8$ (Figure 1 ). This time length was less than the lower bound of $99 \%$ CI (i.e., $1.62 \mathrm{~h} / \mathrm{d}$ ) for

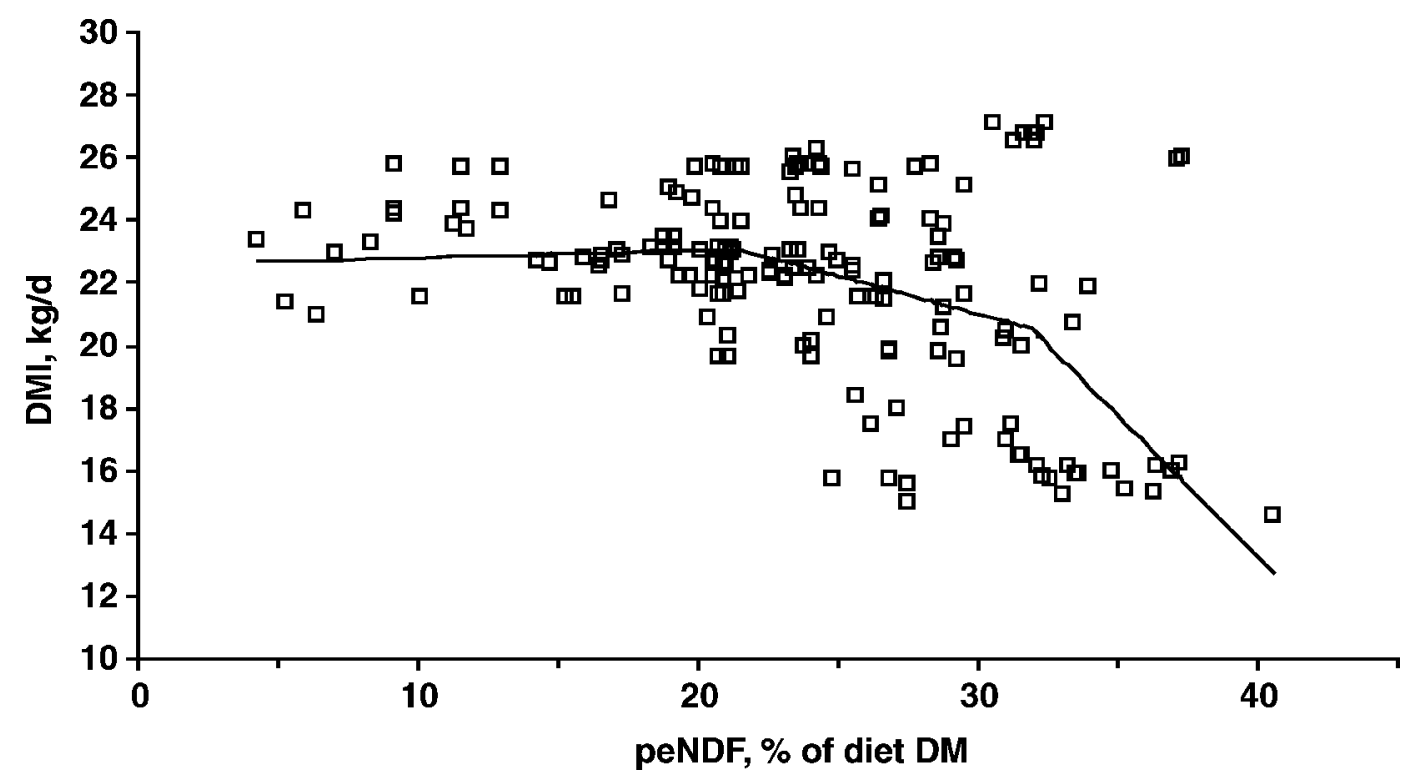

Figure 4. Model showing the relationship between DMI and dietary physically effective NDF (peNDF) in dairy cows: DMI $=\mathrm{a}+\mathrm{b}_{1} \times x$, if $x \leq \mathrm{R}_{1}$; $\mathrm{DMI}=\mathrm{a}+\mathrm{b}_{1} \times \mathrm{R}_{1}+\mathrm{b}_{2} \times\left(x-\mathrm{R}_{1}\right)$, if $\mathrm{R}_{2} \geq x>\mathrm{R}_{1}$; $\mathrm{DMI}=\mathrm{a}+\mathrm{b}_{1} \times \mathrm{R}_{1}+\mathrm{b}_{2} \times\left(\mathrm{R}_{2}-\mathrm{R}_{1}\right)+\mathrm{b}_{3} \times\left(x-\mathrm{R}_{2}\right)$, if $x>\mathrm{R}_{2}\left(\mathrm{a}=22.57 \pm 1.19\right.$, $\mathrm{b}_{1}=$ $0.023 \pm 0.067 ; b_{2}=-0.245 \pm 0.122 ; b_{3}=-0.897 \pm 0.349 ; R_{1}=21.6 \pm 2.92 \%$ peNDF; $R_{2}=31.9 \pm 1.97 \%$ peNDF; $x=$ dietary peNDF $) ;$ root mean square error $=3.03 ; \mathrm{R}^{2}=0.18$. 


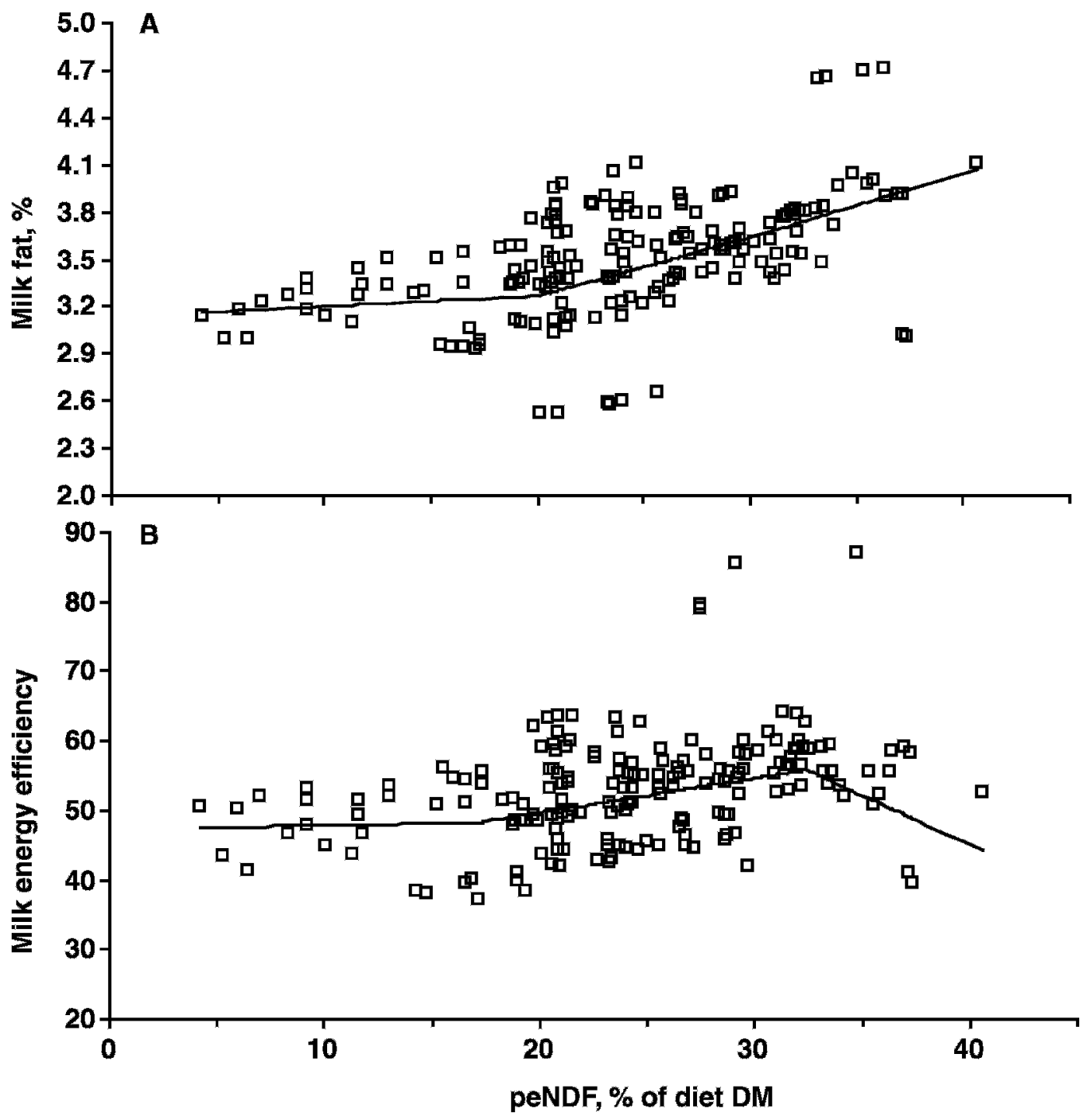

Figure 5. Models showing the relationship between milk fat content (A) or milk energy efficiency (MEE; g milk fat/kg DMI; B) and dietary physically effective NDF (peNDF) in dairy cows: A, Milk fat $=\mathrm{a}+\mathrm{b}_{1} \times x$, if $x \leq \mathrm{R}_{1}$; milk fat $=\mathrm{a}+\mathrm{b}_{1} \times \mathrm{R}_{1}+\mathrm{b}_{2} \times\left(x-\mathrm{R}_{1}\right)$, if $x>\mathrm{R}_{1}$ $\left(\mathrm{a}=3.13 \pm 0.162, \mathrm{~b}_{1}=0.006 \pm 0.011 ; \mathrm{b}_{2}=0.0373 \pm 0.011 ; \mathrm{R}_{1}=20.0 \pm 3.21 \%\right.$ peNDF; $\mathrm{x}=$ dietary peNDF $)$; root mean square error $=0.29$; $\mathrm{R}^{2}=0.37: \mathrm{B}, \mathrm{MEE}=\mathrm{a}+\mathrm{b}_{1} \times x$, if $x \leq \mathrm{R}_{1}$; $\mathrm{MEE}=\mathrm{a}+\mathrm{b}_{1} \times \mathrm{R}_{1}+\mathrm{b}_{2} \times\left(x-\mathrm{R}_{1}\right)$, if $\mathrm{R}_{2} \geq x>\mathrm{R}_{1}$; MEE $=\mathrm{a}+\mathrm{b}_{1} \times \mathrm{R}_{1}+\mathrm{b}_{2} \times\left(\mathrm{R}_{2}-\mathrm{R}_{1}\right)+\mathrm{b}_{3} \times(x-$ $\left.R_{2}\right)$, if $x>R_{2}\left(a=47.32 \pm 3.82, b_{1}=0.052 \pm 0.316 ; b_{2}=0.498 \pm 0.153 ; b_{3}=-1.410 \pm 0.847 ; R_{1}=17.1 \pm 5.59 \%\right.$ peNDF; $R_{2}=32.4 \pm 1.78 \%$ peNDF; $x=$ dietary peNDF); root mean square error $=5.53 ; \mathrm{R}^{2}=0.48$.

the duration that the $\mathrm{pH}$ value was $<5.8$, indicating minimal risk of SARA. This means that a minimal time length of $1 \mathrm{~h} / \mathrm{d}$ exists when ruminal $\mathrm{pH}$ is $<5.8$, and this event is inevitable under feeding conditions in dairy cattle, as summarized in the current database. In fact, the $\mathrm{CI}$ for the time length that ruminal $\mathrm{pH}$ remains $<5.8$, indicating the cut-off point for SARA, was relatively wide (i.e., 5.47 to $15.54 \mathrm{~h} / \mathrm{d}$ or 6.29 to $13.2 \mathrm{~h} /$ $\mathrm{d}$ for 99 and $95 \% \mathrm{CI}$, respectively). On the other hand, the width of 99 and $95 \%$ CI, indicating normal fermentation in the rumen, was narrower (i.e., 1.62 to $5.24 \mathrm{~h} /$ $\mathrm{d}$ and 1.98 to $4.49 \mathrm{~h} / \mathrm{d}$, respectively). This means that the certainty to define the $\mathrm{pH}$ values characterizing normal fermentation in the rumen is higher than the certainty to define the cut-off point of ruminal $\mathrm{pH}$ reflecting SARA conditions. Therefore, our data suggest, with $99 \%$ certainty, that to maintain a lower SARA occurrence (i.e., 1\%), the time length in which the ruminal $\mathrm{pH}$ remains $<5.8$ for longer than $5.24 \mathrm{~h} / \mathrm{d}$ must be avoided.

Indeed, when the time length of ruminal $\mathrm{pH}<5.8$ was increased from 5.4 to $8.8 \mathrm{~h} / \mathrm{d}$ in dairy cows (Gozho et al., 2007) or from 0 to $6.8 \mathrm{~h} / \mathrm{d}$ in steers (Gozho et al., 2006), an acute phase response was activated. Interest- 
Table 6. Best-fit equation showing the response of milk parameters (Y) to different dietary and nondietary factors (X) using backward elimination technique

\begin{tabular}{|c|c|c|c|c|c|c|c|c|}
\hline \multirow[b]{2}{*}{ Predictor $^{1}(\mathrm{X})$} & \multicolumn{4}{|c|}{ Parameter estimates } & \multicolumn{4}{|c|}{ Model statistics ${ }^{2}$} \\
\hline & Intercept & $\mathrm{SE}_{\text {Intercept }}$ & Slope & $\mathrm{SE}_{\text {Slope }}$ & RMSE & $\mathrm{R}^{2}$ & VIF & $P=$ \\
\hline \multicolumn{9}{|c|}{ Actual milk yield, $\mathrm{kg} / \mathrm{d}$} \\
\hline DMI, kg/d & 16.29 & 2.805 & 1.071 & 0.0974 & 4.01 & 0.58 & 1.11 & $<0.001$ \\
\hline DIM & - & - & -0.035 & 0.0068 & - & - & 1.15 & $<0.001$ \\
\hline \multirow{2}{*}{\multicolumn{9}{|c|}{ Milk fat content, $\%$}} \\
\hline & & & & & & & & \\
\hline peNDF, $\%$ of DM & 3.60 & 0.159 & 0.013 & 0.0035 & 0.29 & 0.39 & 1.27 & $<0.001$ \\
\hline RDSG, \% of DM & - & - & -0.022 & 0.0053 & - & - & 1.09 & $<0.001$ \\
\hline DIM & - & - & -0.006 & 0.0017 & - & - & 9.17 & $<0.001$ \\
\hline $\mathrm{DIM}^{2}$ & - & - & 0.0004 & 0.00001 & - & - & 9.59 & $<0.001$ \\
\hline \multicolumn{9}{|l|}{ Milk fat yield, $\mathrm{kg} / \mathrm{d}$} \\
\hline peNDF, $\%$ of DM & 0.589 & 0.109 & 0.006 & 0.0016 & 0.13 & 0.61 & 1.24 & $<0.001$ \\
\hline DMI, kg/d & - & - & 0.037 & 0.0036 & - & - & 1.28 & $<0.001$ \\
\hline RDSG, \% of DM & - & - & -0.015 & 0.0023 & - & - & 1.09 & $<0.001$ \\
\hline DIM & - & - & -0.011 & 0.0022 & - & - & 1.16 & $<0.001$ \\
\hline \multicolumn{9}{|l|}{$3.5 \% \mathrm{FCM}, \mathrm{kg} / \mathrm{d}$} \\
\hline peNDF, $\%$ of DM & 15.28 & 2.718 & 0.138 & 0.0390 & 3.21 & 0.61 & 1.31 & $<0.001$ \\
\hline DMI, kg/d & - & - & 0.848 & 0.0809 & - & - & 1.65 & $<0.001$ \\
\hline RDSG, $\%$ of DM & - & - & -0.371 & 0.0579 & - & - & 1.09 & $<0.001$ \\
\hline DIM & - & - & -0.027 & 0.0054 & - & - & 1.16 & $<0.001$ \\
\hline
\end{tabular}

${ }^{1}$ peNDF $=$ physically effective NDF, measured as the NDF content of TMR multiplied by amount of DM particles retained on a 1.18-mm sieve (Mertens, 1997); RDSF = ruminally degradable starch from forages of TMR; RDSG = ruminally degradable starch from grains of TMR.

${ }^{2} \mathrm{RMSE}$ = root mean square error; VIF = variance inflation factor $(\mathrm{VIF}<10$ is assumed to show no significant multicollinearity among predictor variables).

ingly, presence of the inflammatory response was not associated with disturbances in DMI or in milk production or its composition in dairy cows. Furthermore, in dairy cows fed to experimentally induce SARA, the DMI and milk composition were not affected even when the time length of ruminal $\mathrm{pH}<5.8$ was increased from 0 to $13 \mathrm{~h} / \mathrm{d}$ (Krause and Oetzel, 2005) or from 1.4 to 12.8 h/d (Krajcarski-Hunt et al., 2002), although in situ NDF digestibility significantly declined (Krajcarski-Hunt et al., 2002).

Recent research indicates alterations in ruminal microbial ecology in steers experimetally challenged to induce SARA (Goad et al., 1998; Purvis et al., 2006). In contrast, research conducted in dairy cows fed highconcentrate diets $(>50 \%$ of DM) has shown that when ruminal $\mathrm{pH}$ remains $<5.8$ for 3 to $5 \mathrm{~h} / \mathrm{d}$ it has no affect on the number and activity of fibrolytic bacteria attached to solid or fluid ruminal digesta (Ölschläger et al., 2006; Zebeli et al. 2007a).

\section{Response of Ruminal pH to Dietary Factors}

The greater accuracy of dietary peNDF and FNDF in predicting the response of ruminal $\mathrm{pH}$ compared with total dietary NDF agrees with results of previous studies. For example, Allen (1997) found a positive correlation only between FNDF and ruminal $\mathrm{pH}$, but not between total dietary NDF and $\mathrm{pH}$. In addition, Mertens (1997) also reported a positive curvilinear relationship between dietary peNDF and ruminal $\mathrm{pH}$ in dairy cows. Pitt et al. (1996), using data from sheep, beef cattle, and dairy cattle, also observed a quadratic relationship between effective NDF and ruminal $\mathrm{pH}$. In the study of Pitt et al. (1996), the sheep consumed a high forage diet, which probably accounted for a higher plateau of ruminal $\mathrm{pH}$ in that study (approximately 6.4) compared with 6.27 observed in the present study. Because feeding diets in excess of peNDF may decrease feed intake and lower the efficiency of feed use, the determination of a break-point in dietary peNDF, beyond which no further advantages on ruminal $\mathrm{pH}$ response can be expected, is important particularly in terms of maximization of production responses in high-producing dairy cows.

The content of peNDF in the diet is important in maintaining a stable ruminal environment. Mertens (1997) suggested that feed particles larger than 1.18 $\mathrm{mm}$ (i.e., particles considered in peNDF system) are more effective in stimulating chewing activity and therefore increasing the secretion of saliva and ruminal buffering capacity compared with smaller particles, because the latter readily flow out of the rumen and provide fewer stimuli for chewing activities. However, the increase of ruminal $\mathrm{pH}$ due to increasing dietary peNDF is not necessarily related only to positive effects of peNDF on chewing activity (Zebeli et al., 2007b; Yang and Beauchemin, 2007a). The reason for this could be that the flow of saliva alone is unable to neutralize the 
increasing quantities of VFA and lactate produced after ingesting high amounts of ruminally degradable OM (Allen, 1997).

In addition, dietary peNDF also contributes to formation and maintenance of a stable, thick-packed ruminal raft in dairy cows (Zebeli et al., 2006a). The latter is important in stimulating contractions of the reticulorumen (Yang and Beauchemin, 2007a), which in turn increase the rate of passage and of absorption of VFA molecules across the rumen epithelium (Taylor and Allen, 2005). Increased VFA absorption increases buffering capacity of the rumen because absorption of VFA has been shown to be linked to secretion of $\mathrm{HCO}_{3}{ }^{-}$into the rumen fluid in the ratio of 2:1 (Ash and Dobson, 1963; Gäbel et al., 1991).

The positive effects of peNDF on ruminal fermentation, and hence on attenuating the decline of ruminal $\mathrm{pH}$, may also be related to effects of peNDF on meal patterns. For example, Yang and Beauchemin (2007a) reported that increasing dietary peNDF from 29 to $33 \%$ of the diet DM increased the number of meals per day from 8 to 10. In that study cows consumed less DM per meal, but increased meal frequency. The latter meal pattern was associated with decreased large diurnal fluctuations in ruminal $\mathrm{pH}$, which was reflected in shorter time length of $\mathrm{pH}<5.8$ and higher daily mean ruminal $\mathrm{pH}$ (from 10 to $1 \mathrm{~h} / \mathrm{d}$ and from 6.0 to 6.5 , respectively). Using a modeling approach, Pitt and Pell (1997) estimated that increased meal frequency could decrease the requirements for effective NDF to maintain a certain $\mathrm{pH}$ in the rumen.

Research conducted by Yang and Beauchemin (2006b) also has shown that feeding longer fiber particles shifts the site of starch digestion from rumen into the intestine, lowering the odds for development of ruminal acidosis. Indeed, our results showed positive correlation $(\mathrm{r}=0.50 ; \mathrm{n}=51 ; P<0.001)$ between peNDF content of the diet and the passage rate of fluid digesta out of reticulorumen (results not shown). This indicates acceleration of passage rate of ruminally degradable starch from reticulorumen with increasing peNDF content of the diet. However, in terms of animal health, milk production, and feed efficiency, the relationship between peNDF and RDSG in the diet for high-yielding dairy cows is more complicated than often assumed. Attempts to shift starch digestion from rumen to intestine to improve the efficiency of glucose metabolism have not been very effective. For example, Reynolds (2006) reviewed that although the increased starch digestion in the small intestine increases glucose supply for lactating dairy cow, this occurs at the expense of microbial protein synthesis in the rumen and with an increase in hindgut fermentation and subsequent losses of microbial protein in the feces. Thus, the best way to increase glucose supply is to have an optimal amount of ruminally degradable starch for enough propionate to be converted into glucose in the liver (Huntington, 1997), though without adversely affecting fiber digestibility and other rumen functions (Firkins et al., 2001).

The backward elimination technique showed that of the dietary factors considered, not only peNDF but also dietary RDSG and DMI level improved the prediction of ruminal $\mathrm{pH}$. Allen (1997) also found that including the content or intake of rumen-degradable $\mathrm{OM}$ of the diet in the model together with NDF content and particle length index of forages improved predictions of ruminal $\mathrm{pH}$. The present study showed that increasing dietary RDSG increased requirements for peNDF to stabilize ruminal $\mathrm{pH}$. For example, in simulations for diets containing apparently adequate peNDF levels (i.e., $31.2 \%$ of DM), but differing in RDSG and DMI, the response of ruminal $\mathrm{pH}$ was different. Thus, the probability to maintain a time length not exceeding $5.24 \mathrm{~h} /$ $\mathrm{d}$ in which ruminal $\mathrm{pH}$ remains $<5.8$ (a time assessed as being within the normal fermentation patterns) was $0 \%$ by feeding a diet with $31.2 \%$ peNDF and $14 \%$ RDSG, independently from DMI tested. In contrast, this probability increased by 5 and $45 \%$ when RDSG in the diet increased to $22 \%$ for a theoretical DMI of 20 and $25 \mathrm{~kg} /$ $\mathrm{d}$, respectively (Figure 3 ). It can therefore be concluded that to assess fiber requirements for high-yielding dairy cows, next to peNDF, both RDSG and DMI must be considered. In a previous study, Zebeli and Drochner (2007) assessed that to maintain the ruminal $\mathrm{pH}$ within the normal patterns, the requirements for peNDF in the diet may be lowered to 26 or $22 \%$, when RDSG content in the diet is reduced to $10 \%$ with a 25 or 20 $\mathrm{kg}$ DMI, respectively. Similarly, Yang and Beauchemin (2006b) reported a time length of ruminal $\mathrm{pH}<5.8$ shorter than $5 \mathrm{~h} / \mathrm{d}$ by feeding a corn grain-based diet (54\% concentrate in diet DM) with $<15 \%$ RDSG (estimated according to Offner et al., 2003), with a dietary peNDF content of $26.5 \%$ and DMI of $25 \mathrm{~kg} / \mathrm{d}$. In another study, Yang and Beauchemin (2007a) reported an increased time length of ruminal $\mathrm{pH}<5.8$ from 1.2 to 10.3 $\mathrm{h} / \mathrm{d}$ when RDSG and DMI in the TMR diet increased from 12 to $20 \%$ (estimated according to Offner et al., 2003) and 22 to $24 \mathrm{~kg} / \mathrm{d}$, respectively, whereas peNDF content of TMR decreased from 33 to $29 \%$. Similarly, Silveira et al. (2007) fed barley grain-based diets $(60 \%$ concentrate in diet DM) differing in starch level and ruminal degradability and reported an increased time length of ruminal $\mathrm{pH}<5.8$ from 3.4 to $8.2 \mathrm{~h} / \mathrm{d}$ when RDSG increased from 14 to $24 \%$ (estimated according to Offner et al., 2003) and peNDF content decreased from 33.4 to $29.3 \%$. The latter diet was associated with a significant decline in the total tract NDF digestibility 
from 59 to $51 \%$, although DMI was maintained at 20 $\mathrm{kg} / \mathrm{d}$ throughout the study.

Although increases in DMI are associated with proportional increases in the amount of peNDF and RDSG intakes, the backward elimination procedure showed that increasing DMI may promote fermentation rather than neutralization processes in the rumen, and hence development of SARA. However, this result should be interpreted with caution because of a possible interaction between DMI and other predictors of the model, particularly with RDSG. In fact, ruminal $\mathrm{pH}$ reflects the balance between acid production (i.e., VFA and lactate) in the rumen and acid removal through neutralization and absorption within the rumen (Allen, 1997). In this regard, Shaver (2002) estimated that the flow of salivary buffers remained almost constant when increasing daily intake of rumen-fermentable OM from 4 to $16 \mathrm{~kg} / \mathrm{d}$, whereas fermentation acids produced in the rumen increased linearly, which in turn may increase the risk of SARA in high-producing dairy cows. Firkins et al. (2001) and Stone (2004) concluded that high-yielding dairy cows are at increased risk of SARA due simply to an increased DMI. Oetzel (2000) also suggested limiting the DMI as a strategy to reduce the risk of SARA and improve feed efficiency in highyielding dairy cows. However, results of our study showed that the risk of SARA could be lowered without limiting the DMI, but rather by varying the content of peNDF and RDSG in the diet. Results also suggest that a ratio of peNDF to RDSG in the diet less than 1.5 should be avoided.

The observation that rumen-degradable starch from forages did not affect ruminal $\mathrm{pH}$ in this study was unexpected, as forage sources like corn silage have high content of starch (18 to 35\%), and its ruminal degradability is evaluated to be as high as $85 \%$ (Offner et al., 2003). However, this can be explained by the fact that the ruminal degradability of starch from corn silage is strongly affected by the variety, maturity, inoculant inclusion, and kernel processing (Johnson et al., 2002). In fact, none of these variables were accounted for in the analysis of this study as appropriate data were missing, and hence this aspect warrants further research.

\section{Total-Tract Fiber Digestibility and Rumen Conditions}

Because ruminal $\mathrm{pH}$ has profound effects on microbial populations, it is considered a critical factor in the normal and stable functioning of the rumen. As shown in the present study, variables of rumen conditions (i.e., ruminal $\mathrm{pH}$ or outflow rate of digesta from reticulorumen) have the potential to affect total fiber degradation.
Similarly, Yang et al. (2002) demonstrated that decreasing daily mean ruminal $\mathrm{pH}$ from 6.18 to 5.78 , associated with an increased outflow rate of digesta out of reticulorumen from 2.5 to $3.4 \% / \mathrm{h}$, decreased NDF digestibility in the rumen and in total tract (from 40 to $37 \%$ and 52 to $42 \%$, respectively). By increasing the outflow rate of particulate digesta out of reticulorumen from 2.7 to $4.0 \% / \mathrm{h}$, which was associated with a decreased ruminal mat consistency, Zebeli et al. (2007b) showed a decreased total tract NDF digestibility from 55 to 50\%. Similarly, Boddugari et al. (2001) reported that low digesta consistency in the reticulorumen due to high concentrate levels in the diet was associated with lower entrapment of small particles, increased outflow rate of solid digesta, and decreased ruminal NDF digestibility in dairy cows.

\section{Production Responses to Diet Composition and Dietary Fiber Adequacy}

This modeling approach revealed that increasing peNDF content up to about $32 \%$ slightly reduced DMI and actual milk yield; however, FCM, milk fat yield, and MEE were significantly increased. In fact, the effects of dietary peNDF on DMI in high-producing dairy cows are often controversially discussed. Because of the effects on ruminal physical fill, low peNDF content in the diet is believed to increase feed intake in dairy cows (Dado and Allen, 1995). However, diets low in peNDF and high in readily fermentable carbohydrates may result in increased fermentation intensity and particularly propionate production in the rumen (Zebeli et al., 2007a), which is reported to stimulate plasma insulin response, and this may result in a depression of DMI (Bradford and Allen, 2007) or milk fat synthesis (Reynolds, 2006).

That the content of peNDF up to $32 \%$ in the diet had low constraining effect on DMI in this study may also be explained by a variable DMI capacity of high-yielding dairy cows and by a low constraining effect of peNDF on rumen fill when diets are high in concentrates $(>45 \%$ in DM basis; Allen, 2000). Feeding diets based on corn silage and ground corn with about $32 \%$ peNDF, Kononoff et al. (2003b) and Kononoff and Heinrichs (2003a) reported an average DMI of about $27 \mathrm{~kg} / \mathrm{d}$, and milk yield ranged from 41 to $48 \mathrm{~kg} / \mathrm{d}$ and milk fat content averaged $\geq 3.5 \%$. In contrast, feeding diets with about $26 \%$ peNDF and replacing corn silage with chopped alfalfa haylage, Kononoff and Heinrichs (2003b) reported a lower DMI (about $23 \mathrm{~kg} / \mathrm{d}$ ), milk yield ( $35 \mathrm{~kg} /$ d), and milk fat content (3.3 to 3.4\%). Increasing peNDF content from about 29 to $33 \%$ in a TMR based on alfalfa silage and steam-rolled barley, Yang and Beauchemin (2007b) reported a decreased DMI and milk yield of 
about 2 and $3 \mathrm{~kg} / \mathrm{d}$, respectively. In contrast, milk fat content was increased from 3.4 to $3.8 \%$ resulting in similar amounts of 4\% FCM among treatments and decreased milk efficiency (i.e., FCM/DMI) from 1.40 to 1.28 with increasing peNDF content.

In fact, milk fat content is often used as an indicator for health and fiber adequacy in dairy cows. According to De Brabander et al. (2002), a reduction of milk fat content of about $0.6 \%$ in 1 wk could be considered an indicator for a fiber deficiency in the diet of dairy cows. That the response of milk fat content to dietary peNDF was somewhat lower than the response of ruminal $\mathrm{pH}$ in this study could be explained with a lower sensitivity of milk fat concentration to dietary fiber in cows in early lactation (Allen, 1997; Mertens, 2000), which typically are in a negative energy balance (NRC, 2001). When cows are in a negative energy balance, contribution from mobilized fatty acids increases in direct proportion to the extent of the energy deficit (Bauman and Griinari, 2001), and hence milk fat content may increase regardless of a low milk fat synthesis. In fact, milk fat content was quadratically decreased with increasing DMI in this study. In addition, there was a break-point of peNDF (i.e., $20 \pm 3.2 \%$ ), beyond which milk fat content became more responsive to dietary peNDF (Figure 5A). In a recent study, Mertens (2007) also found that increasing the content of dietary peNDF from 19 to $23 \%$ by adding $5 \%$ wheat straw in the diet was insufficient to alleviate milk fat depression (2.69 vs. $3.30 \%$ milk fat) in dairy cows. Other results of the current study showed that milk fat content depends also on rumendegradable starch in the diet (Table 6). Feeding a high barley starch-based diet, Silveira et al. (2007) reported that $29 \%$ peNDF was insufficient to maintain a milk fat content of $3.4 \%$, and this was associated with lowered daily mean ruminal $\mathrm{pH}$, acetate to propionate ratio, and butyrate proportion in the rumen fluid. In contrast, when increasing the peNDF content of about 32 to $33 \%$ and reducing the content of degradable starch, milk fat content exceeded an average of $3.5 \%$, although diets were based on barley grains (Silveira et al., 2007; Yang and Beauchemin, 2007b) and cows were in early (Yang and Beauchemin, 2007b) or mid lactation (Silveira et al., 2007). This indicates that the balance between dietary peNDF and degradable starch from grains has the capacity to affect fat concentration in the milk by dairy cows by affecting rumen fermentation and metabolism.

Inadequate balance between peNDF and RDSG levels in the diet may alter microbial populations and ruminal biohydrogenation (Weimer et al., 2007), whereby alterations in the pathways of rumen biohydrogenation results in the production of fatty acid intermediates that inhibit fatty acid synthesis in the mammary gland
(Bauman and Griinari, 2003). In addition, the alteration of microbial species in the rumen may also lead to a reduction of acetate and butyrate production, hence resulting in lower lipogenic factors for de novo synthesis of fatty acids in the mammary gland. Indeed, in a recent study, AlZahal et al. (2007) reported that cows experiencing SARA showed lower de novo synthesis of fatty acids $(<16 \mathrm{C})$ and increased trans 18:1 fatty acids, which are considered intermediate products of ruminal biohydrogenation, and this was associated with milk fat depression.

Although milk fat content linearly increases also when diets exceeded $32 \%$ peNDF, this study showed that more than $32 \pm 1.8 \%$ peNDF in the diet is not justified because this may be related to a lower DMI potential and may reduce MEE due likely to lower milk production and milk fat yield. In terms of ruminal $\mathrm{pH}$ and maximization of the MEE in dairy cows, results of the present modeling approach support the inclusion of a maximal content of about 30 to $33 \%$ peNDF in the TMR of lactating dairy cows. However, using the equations developed in the present study, the content of peNDF required to stabilize ruminal $\mathrm{pH}$ and maintain milk fat content without compromising MEE can be arranged based on grain or starch sources included in the diet, DMI, and DIM of the cows.

\section{CONCLUSIONS}

This study showed that to minimize the risk of SARA, a daily mean ruminal $\mathrm{pH}$ lower than 6.16 and a time length in which ruminal $\mathrm{pH}$ is $<5.8$ is longer than 5.24 $\mathrm{h} / \mathrm{d}$ should be avoided. Increasing dietary peNDF up to $31.2 \pm 1.6 \%$ (DM basis) or the ratio of peNDF to RDSG up to $1.45 \pm 0.22$ linearly increased daily mean ruminal $\mathrm{pH}$, of which the asymptotic plateau was achieved at a $\mathrm{pH}$ of 6.20 to 6.27. This study also showed that digestibility of NDF in the total tract depends on ruminal $\mathrm{pH}$ and outflow rate of digesta from reticulorumen; thereby both variables explained $62 \%$ of the variation of NDF digestibility. Feeding diets with a peNDF content from 21.6 to $31.9 \pm 1.97 \%$ slightly decreased DMI and actual milk yield; however, FCM, milk fat yield, and MEE were increased. In conclusion, a level of about 30 to $33 \%$ peNDF in TMR may be considered as the general optimal level of peNDF to minimize the risk of SARA without impairing production responses in high-yielding dairy cows.

\section{ACKNOWLEDGMENTS}

Authors acknowledge the support of this study by German Research Foundation (DFG, code no. DR 92/ 12-1). The assistance of D. Mansmann in compilation of the databases is acknowledged. We would like also 
to gratefully thank 2 anonymous reviewers for their valuable suggestions.

\section{REFERENCES}

Allen, M. S. 1997. Relationship between fermentation acid production in the rumen and the requirement for physically effective fiber. J. Dairy Sci. 80:1447-1462

Allen, M. S. 2000. Effects of diet on short-term regulation of feed intake by lactating dairy cattle. J. Dairy Sci. 83:1598-1624.

AlZahal, O., M. Or-Rashid, S. L. Greenwood, M. S. Douglas, and B. W. McBride. 2007. Subacute ruminal acidosis increases milk fat depression with diets supplemented with polyunsaturated fatty acids. J. Dairy Sci. 90(Suppl. 1):561. (Abstr.)

Ash, R. W., and A. Dobson. 1963. The effect of absorption on the acidity of rumen contents. J. Physiol. 169:39-61.

Bauman, D. E., and J. M. Griinari. 2001. Regulation and nutritional manipulation of milk fat: low-fat milk syndrome. Livest. Prod. Sci. 70:15-29.

Bauman, D. E., and J. M. Griinari. 2003. Nutritional regulation of milk fat synthesis. Annu. Rev. Nutr. 23:203-227.

Beauchemin, K. A., W. Z. Yang, and L. M. Rode. 2003. Effects of particle size of alfalfa based-dairy cow diets on chewing activity, ruminal fermentation, and milk production. J. Dairy Sci. 86:630-643.

Boddugari, K., R. J. Grant, R. Stock, and M. Lewis. 2001. Maximal replacement of forage and concentrate with a new wet corn milling product for lactating dairy cows. J. Dairy Sci. 84:873-884.

Bradford, B. J., and M. S. Allen. 2007. Depression in feed intake by a highly fermentable diet is related to plasma insulin concentration and insulin response to glucose infusion. J. Dairy Sci. 90:38383845 .

Dado, R. G., and M. S. Allen. 1995. Intake limitations, feeding behavior, and rumen function of cows challenged with rumen fill from dietary fiber or inert bulk. J. Dairy Sci. 78:118-133.

De Brabander, D. L., J. L. De Boever, J. M. Vanacker, and N. E. Geerts. 2002. Evaluation and effects of physical structure in dairy cattle nutrition. Pages 182-197 in Recent Developments and Perspectives in Bovine Medicine. M. Kaske, H. Scholz, and M. Höltershinken, ed. Proc. 22nd World Buiatrics Congress, Hannover, Germany.

Dijkstra, J., E. Kebreab, J. A. N. Mills, W. F. Pellikaan, S. Lopez, A. Bannink, and J. France. 2007. Predicting the profile of nutrients available for absorption: From nutrient requirement to animal response and environmental impact. Animal 1:99-111.

Douglas, G. B. 2006. Approximate confidence interval for standard deviation of nonnormal distributions. Comput. Stat. Data Anal. 50:775-782.

Firkins, J. L., M. L. Eastridge, N. R. St-Pierre, and S. M. Noftsger. 2001. Effects of grain variability and processing on starch utilization by lactating dairy cattle. J. Dairy Sci. 79(E Suppl.):E218E238.

Gäbel, G., M. Bestmann, and H. Martens. 1991. Influences of diet, short-chain fatty acids, lactate and chloride on bicarbonate movement across the reticulo-rumen wall of sheep. J. Vet. Med. A 38:523-529.

Goad, D. W., C. L. Goad, and T. G. Nagaraja. 1998. Ruminal microbial and fermentative changes associated with experimentally induced subacute acidosis in steers. J. Anim. Sci. 76:234-241.

Gozho, G. N., D. O. Krause, and J. C. Plaizier. 2006. Rumen lipopolysaccharide and inflammation during grain adaptation and subacute ruminal acidosis in steers. J. Dairy Sci. 89:4404-4413.

Gozho, G. N., D. O. Krause, and J. C. Plaizier. 2007. Ruminal lipopolysaccharide concentration and inflammatory response during grain-induced subacute ruminal acidosis in dairy cows. J. Dairy Sci. 90:856-866.

Huntington, G. B. 1997. Starch utilization by ruminants: From basics to the bunk. J. Anim. Sci. 75:852-867.

Isukapalli, S. S., A. Roy, and P. G. Georgopoulos. 1998. Stochastic response surface methods (SRSMs) for uncertainty characteriza- tion and propagation application to environmental and biological systems. Risk Anal. 18:351-363.

Johnson, L. M., J. H. Harrison, D. Davidson, J. L. Robutti, M. Swift, W. C. Mahanna, and K. Shinners. 2002. Corn silage management I: Effects of hybrid, maturity, and mechanical processing on chemical and physical characteristics. J. Dairy Sci. 85:833-853.

Keunen, J. E., J. C. Plaizier, L. Kyriazakis, T. F. Duffield, T. M. Widowski, M. I. Lindinger, and B. W. McBride. 2002. Effects of a subacute ruminal acidosis model on the diet selection of dairy cows. J. Dairy Sci. 85:3304-3313.

Kononoff, P. J., and A. J. Heinrichs. 2003a. The effect of corn silage particle size and cottonseed hulls on cows in early lactation. J. Dairy Sci. 86:2438-2451.

Kononoff, P. J., and A. J. Heinrichs. 2003b. The effect of reducing alfalfa haylage particle size on cows in early lactation. J. Dairy Sci. 86:1445-1457.

Kononoff, P. J., A. J. Heinrichs, and D. A. Buckmaster. 2003a. Modification of the Penn State forage and total mixed ration particle separator and the effects of moisture content on its measurements. J. Dairy Sci. 86:1858-1863.

Kononoff, P. J., A. J. Heinrichs, and H. A. Lehman. 2003b. The effect of corn silage particle size on eating behavior, chewing activities, and rumen fermentation in lactating dairy cows. J. Dairy Sci. 86:3343-3353

Krajcarski-Hunt, H., J. C. Plaizier, J.-P. Walton, R. Spratt, and B. W McBride. 2002. Short communication: Effect of subacute ruminal acidosis on in situ fiber digestion in lactating dairy cows. J. Dairy Sci. 85:570-573.

Krause, K. M., D. K. Combs, and K. A. Beauchemin. 2003. Effects of increasing levels of refined cornstarch in the diet of lactating dairy cows on performance and ruminal pH. J. Dairy Sci. 86:1341-1353.

Krause, K. M., and G. R. Oetzel. 2005. Inducing subacute ruminal acidosis in lactating dairy cows. J. Dairy Sci. 88:3633-3639.

Krehbiel, C. R., R. A. Stock, D. H. Shain, C. J. Richards, G. A. Ham, R. A. McCoy, T. J. Klopfenstein, R. A. Britton, and R. P. Huffman. 1995. Effect of level and type of fat on subacute acidosis in cattle fed dry-rolled corn finishing diets. J. Anim. Sci. 73:2438-2446.

Mackie, R. I., and F. M. C. Gilchrist. 1979. Change in lactate producing and lactate utilizing bacteria in relation to $\mathrm{pH}$ in the rumen of sheep during stepwise adaptation to a high concentrate diet. Appl. Environ. Microbiol. 38:422-430.

Mertens, D. R. 1997. Creating a system for meeting the fiber requirements of dairy cows. J. Dairy Sci. 80:1463-1481.

Mertens, D. R. 2000. Physically effective NDF and its use in dairy rations explored. Pages in Feedstuffs April 10:11-14.

Mertens, D. R. 2007. Role of effective fiber in reducing milk fat depression in lactating cows fed Rumensin. J. Dairy Sci. 90(Suppl. 1):562. (Abstr.)

National Research Council. 2001. Nutrient Requirement of Dairy Cattle. 7th rev. ed. Natl. Acad. Sci., Washington, DC.

Neter, J., M. H. Kutner, C. J. Nachtsheim, and W. Wasserman. 1996. Applied linear statistical models. 4th ed. McGraw-Hill, Boston, MA.

Oetzel, G. R. 2000. Clinical aspects of ruminal acidosis in dairy cattle. Pages 46-53 in Proc. Am. Assoc. Bovine Practitioners, Rapid City, SD

Offner, A., A. Bach, and D. Sauvant. 2003. Quantitative review of in situ starch degradation in the rumen. Anim. Feed Sci. Technol. 106:81-93.

Ölschläger, V., I. Weber, W. Vahjen, M. Tafaj, O. Simon, and W. Drochner. 2006. Effect of hay particle size and concentrate level on the main cellulolytic bacteria in the rumen of dairy cows. Proc. Soc. Nutr. Physiol. 15:147. (Abstr.)

Pitt, R. E., and A. N. Pell. 1997. Modeling ruminal $\mathrm{pH}$ fluctuations: Interactions between meal frequency and digestion rate. J. Dairy Sci. 80:2429-2441.

Pitt, R. E., J. S. Van Kessel, D. G. Fox, A. N. Pell, M. C. Barry, and P. J. Van Soest. 1996. Prediction of ruminal volatile fatty acids and $\mathrm{pH}$ within the net carbohydrate and protein system. J. Anim. Sci. 74:226-244.

Plaizier, J. C., T. Garner, T. Droppo, and T. Whiting. 2004. Nutritional practices on Manitoba dairy farms. Can. J. Anim. Sci. 84:501-509. 
Purvis, H., S. Fernando, K. Rutz, F. Najar, B. Roe, and U. DeSilva. 2006. Evaluation of rumen microbial fluctuations in response to subacute rumen acidosis using $16 \mathrm{~S}$ rDNA profiles. J. Anim. Sci. 84(Suppl. 1):86. (Abstr.)

Ramsey, P. B., G. W. Mathison, and L. A. Goonewardene. 2001. Relationships between ruminal dry matter and starch disappearance and apparent digestibility of barley grain Anim. Feed Sci. Technol. 94:155-170.

Reynolds, C. K. 2006. Production and metabolic effects of site of starch digestion in dairy cattle. Anim. Feed Sci. Technol. 130:78-94.

Robbins, K. R., A. M. Saxton, and L. L. Southern. 2006. Estimation of nutrient requirements using broken-line regression analysis. J. Anim. Sci. 84(E Suppl.):E155-E165.

SAS. 2003. User's Guide. Statistic, v. 9.1 ed. SAS Inst. Inc., Cary, NC.

Sauvant, D., J. M. Perez, and G. Tran. 2004. Tables of composition and nutritional value of feed materials: Pigs, poultry, cattle, sheep, goats, rabbits, horses, fish. Wageningen Acad. Publ., Wageningen, the Netherlands.

Seo, S., L. O. Tedeschi, C. Lanzas, C. G. Schwab, and D. G. Fox. 2006. Development and evaluation of empirical equations to predict feed passage rate in cattle Anim. Feed Sci. Technol. 128:67-83.

Shaver, R. D. 2002. Rumen acidosis in dairy cattle: Bunk management considerations. Pages 75-81 in Proc. 12th Int. Symp. on Lameness in Ruminants, Orlando, FL.

Silveira, C., M. Oba, W. Z. Yang, and K. A. Beauchemin. 2007. Selection of barley grain affects ruminal fermentation, starch digestibility, and productivity of lactating dairy cows. J. Dairy Sci. 90:2860-2869.

Stone, W. C. 2004. Nutritional approaches to minimize subacute ruminal acidosis and laminitis in dairy cattle. J. Dairy Sci. 87(E Suppl.):E12-E26

St-Pierre, N. R. 2001. Integrating quantitative finding from multiple studies using mixed model methodology. J. Dairy Sci. 84:741-755.

Tafaj, M., Q. Zebeli, B. Junck, H. Steingass, and W. Drochner. 2005. Effects of particle size of a total mixed ration on in vivo ruminal fermentation patterns and inocula characteristics used for in vitro gas production. Anim. Feed Sci. Technol. 123-124:139-154.

Taylor, C. C., and M. S. Allen. 2005. Corn grain endosperm type and brown mibrid 3 corn silage: Ruminal fermentation and $\mathrm{N}$ partitioning in lactating cows. J. Dairy Sci. 88:1434-1442.

Vose, D. 2000. Risk analysis: A quantitative guide. 2nd ed. Wiley, Chichester, UK.

Weimer, P. J., D. M. Stevenson, D. R. Mertens, and E. E. Thomas. 2007. Effect of monensin feeding and withdrawal on ruminal populations of individual bacterial species in cows fed high-starch diets. J. Dairy Sci. 90(Suppl. 1):175. (Abstr.)

Yang, W. Z., and K. A. Beauchemin. 2006a. Increasing the physically effective fiber content of dairy cow diets may lower efficiency of feed use. J. Dairy Sci. 89:2694-2704.

Yang, W. Z., and K. A. Beauchemin. 2006b. Physically effective fiber: method of determination and effects on chewing, ruminal acidosis, and digestion by dairy cows. J. Dairy Sci. 89:2618-2633.

Yang, W. Z., and K. A. Beauchemin. 2007a. Altering physically effective fiber intake through forage proportion and particle length: Chewing and ruminal pH. J. Dairy Sci. 90:2826-2838.

Yang, W. Z., and K. A. Beauchemin. 2007b. Altering physically effective fiber intake through forage proportion and particle length: Digestion and milk production. J. Dairy Sci. 90:3410-3421.

Yang, W. Z., K. A. Beauchemin, and L. M. Rode. 2002. Effects of particle size of alfalfa-based dairy cow diets on site and extent of digestion. J. Dairy Sci. 85:1958-1968.

Yansari, A. T., R. Valizadeh, A. Naserian, D. A. Christensen, P. Yu, and F. E. Shahroodi. 2004. Effects of alfalfa particle size and specific gravity on chewing activity, digestibility, and performance of Holstein dairy cows. J. Dairy Sci. 87:3912-3924.

Zebeli, Q., and W. Drochner. 2007. A simulation model to evaluate the risk of subacute ruminal acidosis in high-yielding dairy cows fed total mixed rations ad libitum. Page 160 in Proc. 13th Int. Conf. Prod. Diseases Farm Anim. Merkur Druck \& Kupier-Zentrum, Leipzig, Germany. (Abstr.)

Zebeli, Q., V. Ölschläger, M. Tafaj, W. Vahjen, B. Junck, O. Simon, and W. Drochner. 2007a. Evaluation of counts of ruminal fibrolytic bacteria and enzyme activities in response to corn silage particle size in high-yielding dairy cows. J. Dairy Sci. 90(Suppl. 1):618619. (Abstr.)

Zebeli, Q., M. Tafaj, B. Metzler, H. Steingass, and W. Drochner. 2006a. New aspects on the contribution of ruminal mat quality on digesta kinetics in reticulorumen of high-producing dairy cows. Übers. Tiernähr. 34:165-196.

Zebeli, Q., M. Tafaj, H. Steingass, B. Metzler, and W. Drochner. $2006 \mathrm{~b}$. Effects of physically effective fiber on digestive processes and milk fat content in early lactating dairy cows fed total mixed rations. J. Dairy Sci. 89:651-668.

Zebeli, Q., M. Tafaj, I. Weber, J. Dijkstra, H. Steingass, and W. Drochner. 2007b. Effects of varying dietary forage particle size in two concentrate levels on chewing activity, ruminal mat characteristics and passage in dairy cows. J. Dairy Sci. 90:1929-1942.

\section{APPENDIX}

Table A1. Publications included in the database used in modeling the responses of ruminal $\mathrm{pH}$ and milk production to diet composition

Allen and Grant (2000)

Bal et al. (2000)

Beauchemin et al. (1997)

Beauchemin et al. (2003a)

Bezerra et al. (2002)

Bhandari et al. (2006)

Bhandari et al. (2007)

Biricik et al. (2007)

Calberry et al. (2003)

Clark and Armentano (1997)

Clark and Armentano (1999)

Clark and Armentano (2002)

Couderc et al. (2006)

Dann et al. (2007)

Einarson et al. (2004)

Fernandez et al. (2004)

Gencoglu and Turkmen (2006)

Gencoglu et al. (2007)

Grant et al. (1990a)

Grant et al. (1990b)
Gulmez and Turkmen (2007)

Junck et al. (2004)

Khezri et al. (2005)

Kleinschmit et al. (2007)

Kononoff and Heinrichs (2003a)

Kononoff and Heinrichs (2003b)

Kononoff et al. (2003)

Krause and Combs (2003)

Krause et al. (2002a)

Krause et al. (2002b)

Krause et al. (2003)

Le Liboux and Peyrand (1998)

Le Liboux and Peyrand (1999)

Leonardi et al. (2005)

Mertens (2007)

Onetti et al. (2003)

Penner et al. (2007)

Plaizier (2004)

Rustomo et al. (2006a)
San Emeterio et al. (2000)

Schwab et al. (2002)

Silveira et al. (2007)

Soita et al. (2000)

Soita et al. (2005)

Tafaj et al. (2005)

Tafaj et al. (2006)

Weber et al. (2006)

Yang and Beauchemin (2006b)

Yang and Beauchemin (2007a)

Yang and Beauchemin (2007b)

Yang et al. (2001a)

Yang et al. (2001b)

Yang et al. (2002)

Yansari et al. (2004)

Zebeli (2006)

Zebeli et al. (2007)

Zebeli et al. (2008)

Zebeli et al. (unpublished results) ${ }^{1}$

${ }^{1}$ Q. Zebeli, K. Frick, and J. Streicher, Univ. Hohenheim, Stuttgart, Germany. 
Table A2. Publications included in the database used in modeling the relationship between daily mean and fluctuation of ruminal $\mathrm{pH}$

\begin{tabular}{lll}
\hline AlZahal et al. (2007a) & Kenelly et al. (1999) & Reis et al. (2001) \\
Bach et al. (2007) & Keunen et al. (2002) & Robinson et al. (1997) \\
Beauchemin and Yang (2005) & Keunen et al. (2003) & Rustomo et al. (2006a) \\
Beauchemin et al. (2000) & Khorasani and Kennelly (2001) & Rustomo et al. (2006b) \\
Beauchemin et al. (2001) & Khorasani et al. (2001a) & San Emeterio et al. (2000) \\
Beauchemin et al. (2003a) & Khorasani et al. (2001b) & Schwab et al. (2002) \\
Beauchemin et al. (2003b) & Koenig et al. (2003) & Schwarzkopf et al. (2004) \\
Bevans et al. (2005) & Kononoff and Heinrichs (2003a) & Silveira et al. (2007) \\
Bowman et al. (2003) & Kononoff and Heinrichs (2003b) & Tafaj et al. (2004) \\
Cottee et al. (2004) & Krajcarski-Hunt et al. (2002) & Tafaj et al. (2005) \\
Cruywagen et al. (2007) & Krause and Combs (2003) & Tafaj et al. (2006) \\
Dado and Allen (1995) & Krause and Oetzel (2005) & Taylor and Allen (2005) \\
Dohme et al. (2007b) & Krause et al. (1998) & Voelker and Allen (2003) \\
Douglas et al. (2007) & Krause et al. (2002) & Weidner and Grant (1994) \\
Fairfield et al. (2007) & Krause et al. (2003) & Weber et al. (2006) \\
Fernandez et al. (2004) & Krehbiel et al. (1995) & Yang and Beauchemin (2006a) \\
Gencoglu and Turkmen (2006) & Le Liboux and Peyraud (1998) & Yang and Beauchemin (2006b) \\
Ghorbani et al. (2002) & Le Liboux and Peyraud (1999) & Yang and Beauchemin (2007) \\
Gozho et al. (2005) & Leonardi et al. (2005) & Yang et al. (1997) \\
Gozho et al. (2006) & Maekawa et al. (2002a) & Yang et al. (2000) \\
Gozho et al. (2007) & Maekawa et al. (2002b) & Yang et al. (2001a) \\
Graf et al. (2005a) & Mutswanga et al. (2002) & Yang et al. (2007) \\
Graf et al. (2005b) & Oba and Allen (2000) & Zebeli (2006) \\
Gulmez and Turkmen (2007) & Osborne et al. (2004) & Zebeli et al. (2007) \\
Harvatine and Allen (2006) & Penner et al. (2007) & Zebeli et al. (2008) \\
Johnson et al. (2002) & Reis and Combs (2000a) & Zebeli et al. (unpublished results) ${ }^{1}$ \\
Johnson et al. (2003) & Reis and Combs (2000b) & \\
&
\end{tabular}

${ }^{1}$ Q. Zebeli, K. Frick, and J. Streicher, Univ. Hohenheim, Stuttgart, Germany.

Table A3. Publications included in the database used in modeling the incidence of subacute ruminal acidosis

\begin{tabular}{lll}
\hline AlZahal et al. (2007a) & Douglas et al. (2007) & Keunen et al. (2003) \\
AlZahal et al. (2007b) & Goad et al. (1998) & Khafipoor et al. (2007a) \\
Cottee et al. (2004) & Gozho et al. (2005) & Khafipoor et al. (2007b) \\
Chiquette et al. (2007) & Gozho et al. (2006) & Krajcarski-Hunt et al. (2002) \\
DeFrain et al. (2002) & Gozho et al. (2007) & Krause and Oetzel (2005) \\
Dohme et al. (2007a) & Keunen et al. (2002) & \\
\hline
\end{tabular}

\section{List of References Used in Meta-Analysis and Listed in Appendix Tables A1, A2, and A3}

Allen, D. M., and R. J. Grant. 2000. Interactions between forage and wet corn gluten feed as sources of fiber in diets for lactating dairy cows. J. Dairy Sci. 83:322-331.

AlZahal, O., E. Kebreab, J. France, M. Froetschel, and B. W. McBride. 2007a. Ruminal temperature may aid in the detection of subacute ruminal acidosis. J. Dairy Sci. 90(Suppl. 1):562. (Abstr.)

AlZahal, O., M. Or-Rashid, S. L. Greenwood, M. S. Douglas and B. W. McBride. 2007b. Subacute ruminal acidosis increases milk fat depression with diets supplemented with polyunsaturated fatty acids. J. Dairy Sci. 90(Suppl. 1):561. (Abstr.)

Bach, A., C. Iglesias, and M. Devant. 2007. Daily rumen $\mathrm{pH}$ pattern of loose-housed dairy cattle as affected by feeding pattern and live yeast supplementation. Anim. Feed Sci. Technol. 136:146-153.

Bal, M. A., R. D. Shaver, A. G. Jirovec, K. J. Shinners, and J. G. Coors. 2000. Crop processing and chop length of corn silage: Effects on intake, digestion, and milk production by dairy cows. J. Dairy Sci. 83:1264-1273.

Beauchemin, K. A., L. M. Rode, and M. V. Eliason. 1997. Chewing activities and milk production of dairy cows fed alfalfa as hay, silage, or dried cubes of hay or silage. J. Dairy Sci. 80:324-333.

Beauchemin, K. A., L. M. Rode, M. Maekawa, D. P. Morgavi, and R. Kampen. 2000. Evaluation of a nonstarch polysaccharidase feed enzyme in dairy cow diets. J. Dairy Sci. 83:543-553.
Beauchemin, K. A., and W. Z. Yang. 2005. Effects of physically effective fiber on intake, chewing activity, and ruminal acidosis for dairy cows fed diets based on corn silage. J. Dairy Sci. 88:2117-2129.

Beauchemin, K. A.,W. Z. Yang, D. P. Morgavi, G. R. Ghorbani, W Kautz, and J. A. Z. Leedle. 2003b. Effects of bacterial directfed microbials and yeast on site and extent of digestion, blood chemistry, and subclinical ruminal acidosis in feedlot cattle. J. Anim. Sci. 81:1628-1640.

Beauchemin, K. A., W. Z. Yang, and L. M. Rode. 2001. Effects of barley grain processing on the site and extent of digestion of beef feedlot finishing diets. J. Anim. Sci. 79:1925-1936.

Beauchemin, K. A., W. Z. Yang, and L. M. Rode. 2003a. Effects of particle size of alfalfa-based dairy cow diets on chewing activity, ruminal fermentation, and milk production. J. Dairy Sci. 86:630-643.

Bevans, D. W., K. A. Beauchemin, K. S. Schwartzkopf-Genswein, J. J. McKinnon, and T. A. McAllister. 2005. Effect of rapid or gradual grain adaptation on subacute acidosis and feed intake by feedlot cattle. J. Anim Sci. 83:1116-1132.

Bezerra, S. E., A. C. Queiroz, F. Maldonado, J. C. Peireira, and M. F. Paulino. 2002. Efeito do perfil granulométrico das partículas dietéticas sobre parâmetros de desempenho de vacas leiteiras em lactacão. R. Bras. Zootec. 31:1511-1520.

Bhandari, S. K., K. H. Ominski, K. M. Wittenberg, and J. C. Plaizier. 2007. Effects of chop length of alfalfa and corn silage on milk production and rumen fermentation of dairy cows. J. Dairy Sci. 90:2355-2366. 
Bhandari, S. K., J. C. Plaizier, K. H. Ominski, and K. M. Wittenberg. 2006. Effects of chop length of alfalfa and oat silage on feed intake, milk production, rumen $\mathrm{pH}$ and feeding behaviour of dairy cows fed total mixed rations. J. Dairy Sci. 84(Suppl. 1):262 (Abstr).

Biricik, H., H. Gencoglu, B. Bozan, B. H. Gulmez, and I. I. Turkmen. 2007. The effect of dry corn gluten feed on chewing activities and rumen parameters in lactating dairy cows. Italian J. Anim. Sci. 6:61-70.

Boddugari, K., R. J. Grant, R. Stock, and M. Lewis. 2001. Maximal replacement of forage and concentrate with a new wet corn milling product for lactating dairy cows. J. Dairy Sci. 84:873-884.

Bowman, G. R., K. A. Beauchemin, and J. A. Shelford. 2003. Fibrolytic enzymes and parity effects on feeding behavior, salivation, and ruminal pH of lactating dairy cows. J. Dairy Sci. 86:565-575.

Calberry, J. M., J. C. Plaizier, M. S. Einarson, and B. W. McBridge. 2003. Effects of replacing chopped alfalfa hay with alfalfa silage in a total mixed ration on production and rumen conditions of lactating dairy cows. J. Dairy Sci. 86:3611-3619.

Chiquette, J., M. J. Allison, and M. A. Rasmussen. 2007. Efficacy of Prevotella briantii 25A and mixture of Enterococcus faecium and Saccharamyces cerevisiae to control sub-clinical acidosis in dairy cows. J. Dairy Sci. 90(Suppl. 1):340-341. (Abstr.)

Clark, P. W., and L. E. Armentano. 1997. Influence of particle size on the effectiveness of beet pulp fiber. J. Dairy Sci. 80:898-904.

Clark, P. W., and L. E. Armentano. 1999. Influence of particle size on the effectiveness of the fiber in corn silage. J. Dairy Sci. 82:581-588.

Clark, P. W., and L. E. Armentano. 2002. Influence of particle size on the effectiveness of the fiber in alfalfa silage. J. Dairy Sci. 85:3000-3007.

Cottee, G., I. Kyriazakis, T. M. Widowski, M. I. Lindinger, J. P. Cant, T. F. Duffield, V. R. Osborne, and B. W. McBride. 2004. The effects of subacute ruminal acidosis on sodium bicarbonate-supplemented water intake for lactating dairy cows. J. Dairy Sci. 87:2248-2253.

Couderc, J. J., D. H. Rearte, G. F. Schroeder, J. I. Ronchi, and F. J. Santini. 2006. Silage chop length and hay supplementation on milk yield, chewing activity, and ruminal digestion by dairy cows. J. Dairy Sci. 89:3599-3608.

Cruywagen, C.W., S. J. Taylor, and M. M. Beya. 2007. The effect of buffering dairy cow diets with limestone, Acid Buf or sodium bicarbonate + limestone on production response and rumen parameters. J. Dairy Sci. 90(Suppl. 1):561. (Abstr.)

Dado R. G., and M. S. Allen. 1995. Intake limitations, feeding behavior, and rumen function of cows challenged with rumen fill from dietary fiber or inert bulk. J. Dairy Sci. 78:118-133.

Dann, H. M., K. W. Cotansch, M. P. Carter, C. S. Ballard, T. Eguchi, and R. J. Grant. 2007. Validation of an on farm tool (Z-Box) for determining a physical effectiveness factor using a bioassay based on chewing activity and ruminal fermentation in lactating dairy cows. J. Dairy Sci. 90(Suppl. 1):563. (Abstr.)

DeFrain, J. M., J. E. Shirley, E. C. Titgemeyer, A. F. Park, and R. T. Ethington. 2002. Impact of feeding a raw soybean hullcondensed corn steep liquor pellet on induced subacute ruminal acidosis in lactating cows. J. Dairy Sci. 85:2000-2008.

Dohme, F., T. J. DeVries, K. Beauchemin, K. M. Krause, and K. S. Schwartzkopf-Genswein. 2007a. Susceptibility of lactating dairy cows to ruminal acidosis depends on the proportion of forage in the diet. J. Dairy Sci. 90 (Suppl. 1):560. (Abstr.)

Dohme, F., A. Scharenberg, and A. Münger. 2007b. Effects of supplements differing in ruminal starch availability on milk yield, blood metabolites and ruminal fermentation in cows grazing ryegrass/ clover pasture. Proc. Soc. Nutr. Physiol. 16:27. (Abstr.)

Douglas, M. S., O. AlZahal, S. L. Greenwood, M. Or-Rashid, and B. W. McBride. 2007. Effect of added yeast culture on lactating dairy cows with subacute ruminal acidosis. J. Dairy Sci. 90 (Suppl. 1):352. (Abstr.)

Einarson, M. S., J. C. Plaizier, and K. M. Wittenberg. 2004. Effects of barley silage chop length on productivity and rumen conditions of lactating dairy cows fed total mixed ration. J. Dairy Sci. 87:2987-2996.
Fairfield, A. M., J. C. Plaizier, T. F. Duffield, M. I. Lindinger, R. Bagg, P. Dick, and B. W. McBride. 2007. Effects of prepartum administration of a monensin controlled release capsule on rumen $\mathrm{pH}$, feed intake, and milk production of transition dairy cows. J. Dairy Sci. 90:937-945.

Fernandez, I., C. Martin, M. Champion, and B. Michalet-Doreau. 2004. Effect of corn hybrid and chop length of whole-plant corn silage on digestion and intake by dairy cows. J. Dairy Sci. 87:1298-1309.

Gencoglu, H., and I. I. Turkmen. 2006. Effects of forage source on chewing and rumen fermentation in lactating dairy cows. Rev. Med. Vet. 157:463-470.

Gencoglu, H., I. I. Turkmen, G. Deniz, and H. Biricik. 2007. The effect of partial replacement of corn silage on rumen degradability, milk production and composition in lactating primiparous dairy cows. Italian J. Anim. Sci. 6:71-80.

Ghorbani, G. R., D. P. Morgavi, K. A. Beauchemin, and J. A. Z. Leedle. 2002. Effects of bacterial direct-fed microbials on ruminal fermentation, blood variables, and the microbial populations of feedlot cattle. J. Anim Sci. 80:1977-1985.

Goad, D. W., C. L. Goad, and T. G. Nagaraja. 1998. Ruminal microbial and fermentative changes associated with experimentally induced subacute acidosis in steers. J. Anim Sci. 76:234-241.

Gozho, G. N., D. O. Krause, and J. C. Plaizier. 2006. Rumen lipopolysaccharide and inflammation during grain adaptation and subacute ruminal acidosis in steers. J. Dairy Sci. 89:4404-4413.

Gozho, G. N., D. O. Krause, and J. C. Plaizier. 2007. Ruminal lipopolysaccharide concentration and inflammatory response during grain-induced subacute ruminal acidosis in dairy cows. J. Dairy Sci. 90:856-866.

Gozho, G. N., J. C. Plaizier, D. O. Krause, A. D. Kennedy, and K. M. Wittenberg. 2005. Subacute ruminal acidosis induces ruminal lipopolysaccharide endotoxin release and triggers an inflammatory response. J. Dairy Sci. 88:1399-1403.

Graf, M. C., M. Kreuzer, and F. Dohme. 2005a. Influence of supplementing hay to grass once or three times per day on the effectiveness of the fibre as determined by changes in ruminal $\mathrm{pH}$, chewing activity and milk composition of cows. Anim. Res. 54:321-335.

Graf, M. C., M. Kreuzer, and F. Dohme. 2005b. Effects of supplemental hay and corn silage versus full-time grazing on ruminal $\mathrm{pH}$ and chewing activity of dairy cows. J. Dairy Sci. 88:711-725.

Grant, R. J., V. F. Colenbrander, and D. R. Mertens. 1990a. Milk fat depression in dairy cows: Role of particle size of alfalfa hay. J. Dairy Sci. 73:1823-1833.

Grant, R. J., V. F. Colenbrander, and D. R. Mertens. 1990b. Milk fat depression in dairy cows: Role of silage particle size. J. Dairy Sci. 73:1834-1842.

Gulmez, B. H., and I. I. Turkmen. 2007. Effect of starch sources with different degradation rates on ruminal fermentation of lactating dairy cows. Rev. Med. Vet. 158:92-99.

Harvatine K. J., and M. S. Allen. 2006. Effects of fatty acid supplements on feed intake, and feeding and chewing behavior of lactating dairy cows. J. Dairy Sci. 89:1104-1112.

Johnson, L. M., J. H. Harrison, D. Davidson, W. C. Mahanna, and K. Shinners. 2003. Corn silage management: Effects of hybrid, chop length, and mechanical processing on digestion and energy content. J. Dairy Sci. 86:208-231.

Johnson, L. M., J. H. Harrison, D. Davidson, M. Swift, W. C. Mahanna, and K. Shinners. 2002. Corn silage management iii: effects of hybrid, maturity, and processing on nitrogen metabolism and ruminal fermentation. J. Dairy Sci. 85:2928-2947.

Junck, B., M. Tafaj, Q. Zebeli, R. Funk, H. Steingass, and W. Drochner. 2004. Einfluss der Häcksellänge auf Strukturwert und Qualität der Maissilage (Influence of length of the cut on the physical evaluation and quality of corn silage). Page 96 in Proc. 116th VDLUFA Congress, Rostock, Germany. (Abstr.)

Kennelly, J. J., B. Robinson, and G. R. Khorasani. 1999. Influence of carbohydrate source and buffer on rumen fermentation characteristics, milk yield, and milk composition in early-lactation Holstein cows. J. Dairy Sci. 82:2486-2496.

Keunen, J. E., J. C. Plaizier, I. Kyriazakis, T. F. Duffield, T. M. Widowski, M. I. Lindinger, and B. W. McBride. 2003. Short com- 
munication: Effects of subacute ruminal acidosis on free-choice intake of sodium bicarbonate in lactating dairy cows. J. Dairy Sci. 86: 954-957.

Keunen, J. E., J. C. Plaizier, L. Kyriazakis, T. F. Duffield, T. M. Widowski, M. I. Lindinger, and B. W. McBride. 2002. Effects of a subacute ruminal acidosis model on the diet selection of dairy cows. J. Dairy Sci. 85: 3304-3313.

Khafipoor, E., D. O. Krause, and J. C. Plaizier. 2007a. Grain-induced subacute ruminal acidosis (SARA) stimulates translocation of lipopolysaccharide (LPS) into the blood, and increases acute phase proteins in bovine plasma and milk. J. Dairy Sci. 90 (Suppl. 1):654. (Abstr.)

Khafipoor, E., D. O. Krause, and J. C. Plaizier. 2007b. Induction of subacute ruminal acidosis (SARA) by replacing alfalfa hay with alfalfa pellets does not stimulate inflammatory response in lactating dairy cows. J. Dairy Sci. 90(Suppl. 1):654. (Abstr.)

Khezri, A., A. Nikkhah, A. Z. Shahneh, and M. H. Fooladi. 2005. The effect of reducing alfalfa hay cut length on TMR particle size distribution, rumen $\mathrm{pH}$ and chewing activity of cows in early lactation using Penn State Particles Separator (PSPS). Page 75 in Proc. British Soc. Anim. Sci., Midlothian, UK. (Abstr.)

Khorasani, G. R., and J. J. Kennelly. 2001. Influence of carbohydrate source and buffer on rumen fermentation characteristics, milk yield, and milk composition in late-lactation Holstein cows. J. Dairy Sci. 84:1707-1716.

Khorasani, G. R., E. K. Okine, and J. J. Kennelly. 2001a. Effects of substituting barley grain with corn on ruminal fermentation characteristics, milk yield, and milk composition of Holstein cows. J. Dairy Sci. 84:2760-2769.

Khorasani, G. R., E. K. Okine, and J. J. Kennelly. 2001b. Effects of forage source and amount of concentrate on rumen and intestinal digestion of nutrients in late-lactation cows. J. Dairy Sci. $84: 1156-1165$.

Kleinschmit, D. H., D. J. Schingoethe, A. R. Hippen, and K. F. Kalscheur. 2007. Dried distillers grains plus solubles with corn silage or alfalfa hay as the primary forage source in dairy cows. J. Dairy Sci. 90:5587-5599.

Koenig, K. M., K. A. Beauchemin, and L. M. Rode. 2001. Effect of grain processing and silage on microbial protein synthesis and nutrient digestibility in beef cattle fed barley-based diets. J. Anim. Sci. 81:1057-1067.

Kononoff, P. J., and A. J. Heinrichs. 2003a. The effect of corn silage particle size and cottonseed hulls on cows in early lactation. J. Dairy Sci. 86:2438-2451.

Kononoff, P. J., and A. J. Heinrichs. 2003b. The effect of reducing alfalfa haylage particle size on cows in early lactation. J. Dairy Sci. 86:1445-1457.

Kononoff, P. J., A. J. Heinrichs, and H. A. Lehman. 2003. The effect of corn silage particle size on eating behavior, chewing activities, and rumen fermentation in lactating dairy cows. J. Dairy Sci. 86:3343-3353

Krajcarski-Hunt, H., J. C. Plaizier, J.-P. Walton, R. Spratt, and B. W McBride. 2002. Short communication: Effect of subacute ruminal acidosis on in situ fiber digestion in lactating dairy cows. J. Dairy Sci. 85:570-573.

Krause K. M., and G. R. Oetzel. 2005. Inducing subacute ruminal acidosis in lactating dairy cows. J. Dairy Sci. 88:3633-3639.

Krause, K. M., and D. K. Combs. 2003. Effects of forage particle size, forage source, and grain fermentability on performance and ruminal pH in midlactation cows. J. Dairy Sci. 86:1382-1397.

Krause, K. M., D. K. Combs, and K. A. Beauchemin, 2002a. Effects of forage particle size and grain fermentability in midlactation dairy cows. II. Ruminal $\mathrm{pH}$ and chewing activity. J. Dairy Sci. 85:1947-1957.

Krause, K. M., D. K. Combs, and K. A. Beauchemin. 2002b. Effects of forage particle size and grain fermentability in midlactation cows. I. Milk production and diet digestibility. J. Dairy Sci. 85:1936-1946.

Krause, K. M., D. K. Combs, and K. A. Beauchemin. 2003. Effects of increasing levels of refined cornstarch in the diet of lactating dairy cows on performance and ruminal pH. J. Dairy Sci. 86: 1341-1353.
Krause, M., K. A. Beauchemin, L. M. Rode, B. I. Farr, and P. Norgaard. 1998. Fibrolytic enzyme treatment of barley grain and source of forage in high-grain diets fed to growing cattle. J. Anim. Sci. 76:2912-2920.

Krehbiel, C. R., R. A. Stock, D. H. Shain, C. J. Richards, G. A. Ham, R. A. McCoy, T. J. Klopfenstein, R. A. Britton, and R. P. Huffman. 1995. Effect of level and type of fat on subacute acidosis in cattle fed dry-rolled corn finishing diets. J. Anim. Sci. 73:2438-2446.

Le Liboux, S., and J. L. Peyrand. 1998. Effect of forage particle size and intake level on fermentation patterns and sites and extent of digestion in dairy cows fed mixed diets. Anim. Feed Sci. Technol. 73:131-150.

Le Liboux, S., and J. L. Peyrand. 1999. Effect of forage particle size and feeding frequency on fermentation patterns and sites and extent of digestion in dairy cows fed mixed diets. Anim. Feed Sci. Technol. 76:297-319.

Leonardi, C., K. J. Shinners, and L. E. Armentano. 2005. Effect of different dietary geometric mean length particle length and particle size distribution of oat silage on feeding behavior and productive performance of dairy cattle. J. Dairy Sci. 88:698-710.

Maekawa, M., K. A. Beauchemin, and D. A. Christensen. 2002a. Effect of concentrate level and feeding management on chewing activities, saliva production, and ruminal $\mathrm{pH}$ of lactating dairy cows. J. Dairy Sci. 85:1165-1175.

Maekawa, M., K. A. Beauchemin, and D. A. Christensen. 2002b. Chewing activity, saliva production, and ruminal $\mathrm{pH}$ of primiparous and multiparous lactating dairy cows. J. Dairy Sci. 85:1176-1182.

Mertens, D. R. 2007. Role of effective fiber in reducing milk fat depression in lactating cows fed Rumensin. J. Dairy. Sci. 90(Suppl. 1):562. (Abstr.)

Mutsvangwa, T., J. P. Walton, J. C. Plaizier, T. F. Duffield, R. Bagg, P. Dick, G. Vessie, and B. W. McBride. 2002. Effects of a monensin controlled-release capsule or premix on attenuation of subacute ruminal acidosis in dairy cows. J. Dairy Sci. 85:3454-3461.

Oba M., and M. S. Allen. 2000. Effects of brown midrib 3 mutation in corn silage on productivity of dairy cows fed two concentrations of dietary neutral detergent fiber: 1 . Feeding behavior and nutrient utilization. J. Dairy Sci. 83:1333-1341.

Onetti, S. G., R. D. Shaver, S. J. Bertics, and R. R. Grummer. 2003. Influence of corn silage particle length on the performance of lactating dairy cows fed supplemental tallow. J. Dairy Sci. 86:2949-2957.

Osborne, J. K., T. Mutsvangwa, O. Alzahal, T. F. Duffield, R. Bagg, P. Dick, G. Vessie, and B. W. McBride. 2004. Effects of monensin on ruminal forage degradability and total tract diet digestibility in lactating dairy cows during grain-induced subacute ruminal acidosis. J. Dairy Sci. 87:1840-1847.

Penner, G. B., K. A. Beauchemin, and T. Mutsvangwa. 2007. Severity of ruminal acidosis in primiparous Holstein cows during the periparturient period. J. Dairy Sci. 90:365-375.

Plaizier, J. C. 2004. Replacing chopped alfalfa hay with alfalfa silage in barley grain and alfalfa based total mixed rations for lactating dairy cows. J. Dairy Sci. 87:2495-2505.

Reis R. B., and D. K. Combs. 2000a. Effects of increasing levels of grain supplementation on rumen environment and lactation performance of dairy cows grazing grass-legume pasture. J. Dairy Sci. 83:2888-2898

Reis R. B., and D. K. Combs. 2000b. Effects of corn processing and supplemental hay on rumen environment and lactation performance of dairy cows grazing grass-legume pasture. J. Dairy Sci. 83:2529-2538.

Reis, R. B., F. San Emeterio, D. K. Combs, L. D. Satter, and H. N. Costa. 2001. Effects of corn particle size and source on performance of lactating cows fed direct-cut grass-legume forage. J. Dairy Sci. 84:429-441.

Robinson, P. H., M. Gill, and J. J. Kennelly. 1997. Influence of time of feeding a protein meal on ruminal fermentation and forestomach digestion in dairy cows. J. Dairy Sci. 80:1366-1373.

Rustomo, B., O. Alzahal, J. P. Cant, M. Z. Fan, T. F. Duffield, N. E. Odongo, and B.W. McBride. 2006b. Acidogenic value of feeds II. Effects of rumen acid load from feeds on dry matter intake, rumi- 
nal $\mathrm{pH}$, fibre degradability and milk production in the lactating dairy cow. Can. J. Anim. Sci. 86:119-127.

Rustomo, B., O. AlZahal, N. E. Odongo, T. F. Duffield, and B. W. McBride. 2006a. Effects of rumen acid load from feed and forage particle size on ruminal $\mathrm{pH}$ and dry matter intake in the lactating dairy cow. J. Dairy Sci. 89:4758-4768.

San Emeterio, F., R. B. Reis, W. E. Campos, and L. D. Satter. 2000. Effect of coarse or fine grinding on utilization of dry or ensiled corn by lactating dairy cows. J. Dairy Sci. 83:2839-2848.

Schwab, E. C., R. D., Shaver, K. J. Shinners, J. G. Lauer, and J. G. Coors. 2002. Processing and chop length in brown-midrib corn silage on intake, digestion, and milk production by dairy cows. J. Dairy Sci. 85:613-623.

Schwartzkopf-Genswein, K. S., K. A. Beauchemin, T. A. McAllister, D. J. Gibb, M. Streeter, and A. D. Kennedy. 2004. Effect of feed delivery fluctuations and feeding time on ruminal acidosis, growth performance, and feeding behavior of feedlot cattle. J. Anim. Sci. 82:3357-3365.

Silveira, C., M. Oba, W. Z. Yang, and K. A. Beauchemin. 2007. Selection of barley grain affects ruminal fermentation, starch digestibility, and productivity of lactating dairy cows. J. Dairy Sci. 90:2860-2869.

Soita, H. W., D. A. Christensen, and J. J. McKinnon. 2000. Influence of particle size on the effectiveness of the fiber in barley silage. J. Dairy Sci. 83:2295-2300.

Soita, H. W., M. Fehr, D. A. Christensen, and T. Mutsvangwa. 2005. Effects of corn silage particle length and forage:concentrate ratio on milk fatty acid composition in dairy cows fed supplemental flaxseed. J. Dairy Sci. 88:2813-2819.

Tafaj, M., B. Junck, A. Maulbetsch, H. Steingass, H.-P. Piepho, and W. Drochner. 2004. Digesta characteristics of dorsal, middle and ventral rumen of cows fed with different hay qualities and concentrates levels. Arch. Anim. Nutr. 58:325-342.

Tafaj, M., Q. Zebeli, A. Maulbetsch, H. Steingass, and W. Drochner. 2006. Effects of fibre concentration of diets consisting of hay and slowly degradable concentrate on the fermentation patterns and digesta particle size in the rumen of mid-lactation dairy cows. Arch. Anim. Nutr. 60:254-266.

Tafaj, M., Q. Zebeli, B. Junck, H. Steingass, and W. Drochner. 2005. Effects of particle size of a total mixed ration on in vivo ruminal fermentation patterns and inocula characteristics used for in vitro gas production. Anim. Feed Sci. Technol. 123-124:139-154.

Taylor, C. C., and M. S. Allen. 2005. Corn grain endosperm type and brown midrib 3 corn silage: Ruminal fermentation and $\mathrm{N}$ partitioning in lactating cows. J. Dairy Sci. 88:1434-1442.

Voelker J. A., and M. S. Allen. 2003. Pelleted beet pulp substituted for high-moisture corn: 3. effects on ruminal fermentation, $\mathrm{pH}$, and microbial protein efficiency in lactating dairy cows. J. Dairy Sci. 86:3562-3570.

Weber, I., H. Steingass, M. Tafaj, and W. Drochner. 2006. Einfluss der Kohlenhydrat-zusammensetzung von Kraftfuttermischungen in Totalen Mischrationen auf Futteraufnahme, Leistungsparameter und Fermentation im Pansen bei Milchkühen (Effects of composition of concentrates of total mixed rations on dry matter intake, performance and ruminal fermentation in dairy cows). Page 98 in Proc. 118th VDLUFA Congress, VDLUFA Verlag, Darmstadt, Germany.

Weidner, S. J., and R. J. Grant. 1994. Altered ruminal mat consistency by high percentages of soyabean hulls to lactating cows. J. Dairy Sci. 77:522-532.

Yang W. Z., and K. A. Beauchemin. 2007a. Altering physically effective fiber intake through forage proportion and particle length: Chewing and ruminal pH. J. Dairy Sci. 90:2826-2838.

Yang, W. Z., and K. A. Beauchemin. 2006a. Effects of physically effective fiber on chewing activity and ruminal $\mathrm{pH}$ of dairy cows fed diets based on barley silage. J. Dairy Sci. 89:217-228.

Yang, W. Z., and K. A. Beauchemin. 2007b. Altering physically effective fiber intake through forage proportion and particle length: Digestion and milk production. J. Dairy Sci. 90:3410-3421.

Yang, W. Z., and K. A. Beauchemin. 2006b. Physically effective fiber: Method of determination and effects on chewing, ruminal acidosis, and digestion by dairy cows. J. Dairy Sci. 89:2618-2633.

Yang, W. Z., C. Benchaar, B. N. Ametaj, A. V. Chaves, M. L. He, and T. A. McAllister. 2007. Effects of garlic and juniper berry essential oils on ruminal fermentation and on the site and extent of digestion in lactating cows. J. Dairy Sci. 90:5671-5681.

Yang, W. Z., K. A. Beauchemin, and L. M. Rode. 2000. Effects of barley grain processing on extent of digestion and milk production of lactating cows. J. Dairy Sci. 83:554-568.

Yang, W. Z., K. A. Beauchemin, and L. M. Rode. 2001a. Effects of grain processing, forage to concentrate ratio, and forage particle size on rumen $\mathrm{pH}$ and digestion in dairy cows. J. Dairy Sci. 84:2203-2216.

Yang, W. Z., K. A. Beauchemin, and L. M. Rode. 2001b. Barley processing, forage:concentrate, and forage length effects on chewing and digesta passage in lactating cows. J. Dairy Sci. 84:2709-2720.

Yang, W. Z., K. A. Beauchemin, and L. M. Rode. 2002. Effects of particle size of alfalfa-based dairy cow diets on site and extent of digestion. J. Dairy Sci. 85:1958-1968.

Yang, W. Z., K. A. Beauchemin, K. M. Koenig, and L. M. Rode. 1997. Comparison of hull-less barley, barley, or corn for lactating cows: effects on extent of digestion and milk production. J. Dairy Sci. 80:2475-2486.

Yansari, A. T., R. Valizadeh, A. Naserian, D. A. Christensen, P. Yu, and F. E. Shahroodi. 2004. Effects of alfalfa particle size and specific gravity on chewing activity, digestibility, and performance of Holstein dairy cows. J. Dairy Sci. 87:3912-3924.

Zebeli, Q. 2006. Einfluss der Partikellänge von Totalmischrationen (TMR) auf die Digestaschichtung und Verdauungsvorgänge im Pansen hochleistender Milchkühe. PhD Dissertation, University of Hohenheim, Shaker Verlag, Aachen, Germany.

Zebeli, Q., V. Ölschläger, M. Tafaj, W. Vahjen, B. Junck, O. Simon, and W. Drochner. 2007. Evaluation of counts of ruminal fibrolytic bacteria and enzyme activities in response to corn silage particle size in high-yielding dairy cows. J. Dairy Sci. 90(Suppl. 1):618619. (Abstr.)

Zebeli, Q., M. Tafaj, I. Weber, H. Steingass, and W. Drochner. 2008. Effects of dietary forage particle size and concentrate level on fermentation profile, in vitro degradation characteristics and concentration of liquid- or solid-associated bacterial mass in the rumen of dairy cows. Anim. Feed Sci. Technol. 140:307-345. 